\title{
Team of Rivals? Toward a New Model of the Corporate Attorney-Client Relationship
}

\section{Citation}

David B. Wilkins, Team of Rivals? Toward a New Model of the Corporate Attorney-Client Relationship, 78 Fordham L. Rev. 2067 (2010)

\section{Published Version}

http://ir.lawnet.fordham.edu/flr/vol78/iss5/2/

\section{Permanent link}

http://nrs.harvard.edu/urn-3:HUL.InstRepos:12785991

\section{Terms of Use}

This article was downloaded from Harvard University's DASH repository, and is made available under the terms and conditions applicable to Open Access Policy Articles, as set forth at http:// nrs.harvard.edu/urn-3:HUL.InstRepos:dash.current.terms-of-use\#OAP

\section{Share Your Story}

The Harvard community has made this article openly available.

Please share how this access benefits you. Submit a story.

\section{Accessibility}




\section{Fordham Law Review}

Volume 78 | Issue 5

Article 2

2010

\section{Team of Rivals? Toward a New Model of the Corporate Attorney-Client Relationship}

David B. Wilkins

\section{Recommended Citation}

David B. Wilkins, Team of Rivals? Toward a New Model of the Corporate Attorney-Client Relationship, 78 Fordham L. Rev. 2067 (2010). Available at: http://ir.lawnet.fordham.edu/flr/vol78/iss5/2

This Article is brought to you for free and open access by FLASH: The Fordham Law Archive of Scholarship and History. It has been accepted for inclusion in Fordham Law Review by an authorized administrator of FLASH: The Fordham Law Archive of Scholarship and History. For more

information, please contact tmelnick@law.fordham.edu. 


\title{
TEAM OF RIVALS? TOWARD A NEW MODEL OF THE CORPORATE ATTORNEY-CLIENT RELATIONSHIP
}

\author{
David B. Wilkins*
}

\section{INTRODUCTION}

From its founding, University College London (UCL) has played a key role in defining - and critiquing - the traditional model of the attorneyclient relationship. In this article, I will argue that this rich history has much to teach us about the evolving relationship between large companies and their primary outside law firms as we ponder the likely consequences of the current financial crisis.

I will do so by challenging the unstated assumption underlying one of the most widely quoted statements in legal ethics, made by one of UCL's most important founding fathers, Lord Henry Brougham. There is arguably no more quoted, or in the minds of many lawyers beloved, understanding of the duties owed by an advocate to his or her client than Brougham's legendary speech in defense of Queen Caroline. Speaking on the floor of

* Lester Kissel Professor of Law and Faculty Director of the Program on the Legal Profession and the Center on Lawyers and the Professional Services Industry, Harvard Law School. This chapter was originally presented as the Current Legal Problems Lecture at University College London in March 2008. A version of this paper was published in 62 CURRENT Legal ProBs. 478 (2010). I thank Lucy Page and the rest of the terrific people at Oxford University Press for giving me permission to reprint the article here. The piece has been updated slightly to reflect certain events that have transpired since the original version was finalized for publication. In addition, I wish to thank Colm O'Cinneide for arranging the lecture and for his outstanding comments on my initial draft. I also wish to thank the faculty and students who attended that event for their helpful comments. I would also like to thank faculty and students at Yale Law School, Georgetown University Law Center, University of California at Hastings College of Law, Stetson University College of Law, University of Iceland Faculty of Law, University of Stockholm Faculty of Law, University of Vancouver Faculty of Law, and my home institution of Harvard Law School for helpful comments when I presented versions of the chapter at these institutions. John Coates, Ben Heineman, Robert Mnookin, Mari Sako, Bill Simon, Detlev Vagts, and Ben Zipursky also provided invaluable feedback on prior drafts. Chris Assise and Jason Silverstein gave terrific research support and feedback on prior drafts. Finally, I wish to thank my colleagues on the Harvard Law School Corporate Purchasing Project, Michele Beardslee, John Coates, Young-Kyu Kim, Ashish Nanda, and Sean Williams, for their outstanding work in helping to produce the data from that project discussed below. The phrase "team of rivals" is used with apologies to Doris Kearns Goodwin and her book of the same title, which examines how the political rivals that made up Abraham Lincoln's wartime Cabinet succeeded in working closely together to bring the American Civil War to a successful conclusion, and to the current President, Vice President, and Secretary of State of the United States, who some have referred to as comprising a modem-day "team of rivals." 
the House of Lords in 1820, Lord Brougham eloquently stated what many still believe to be the essence of the lawyer's role:

"[A]n advocate, in the discharge of his duty, knows but one person in all the world, and that person is his client. To save that client by all means and expedients, and at all hazards and costs to other persons, and, amongst them, to himself, is his first and only duty; and in performing this duty he must not regard the alarm, the torments, the destruction which he may bring upon others. Separating the duty of a patriot from that of an advocate, he must go on reckless of the consequences, though it should be his unhappy fate to involve his country in confusion."1

For almost two centuries, these words have stood as the embodiment of the ideal of zealous advocacy that lawyers owe to their clients. ${ }^{2}$ But of late, there have also been many who have questioned whether such an extreme standard of partisanship-ignoring the "alarm," "torment," and "destruction" of others-is the proper standard for lawyers to take in all circumstances. ${ }^{3}$ Specifically, I and others have argued that whatever the value of Brougham's conception in the context in which he made his famous claim-i.e., the representation of an individual criminal defendant facing the unchecked power of the King in circumstances where the defendant's head was quite literally on the line-this understanding has much less to recommend it when we consider how corporate lawyers ought to conceive of their duties, particularly in the area of regulatory compliance. $^{4}$

Today, these concerns are especially salient. As the spotlight of blame shines its accusatory light on the cast of characters involved in the current economic meltdown, it is only a matter of time before the inside and outside lawyers who represented the banks and other financial institutions we are currently bailing out will be called upon to take their turn in the dock. ${ }^{5}$

1. See Monroe H. Freedman, Henry Lord Brougham, Written by Himself, 19 GEO. J. Legal ETHICS 1213, 1215 (2006) (quoting 2 The TRIAL OF QueEN CAROLINE 3 (1821)).

2. Id. (discussing the many admiring references to Brougham's quote).

3. William Simon was among the first to mount this critique, see generally William $\mathrm{H}$. Simon, The Ideology of Advocacy: Procedural Justice and Professional Ethics, 1978 WIS. L. REV. 29, but there have now been many others. See generally DAVID LuBAN, LAWYERS AND JUSTICE: AN ETHICAL STUDY (1988); DEBORAH L. RHODE, IN THE INTERESTS OF JUSTICE: REForming THE LEGAL PROFESSION (2000); Robert W. Gordon, The Independence of Lawyers, 68 B.U. L. REV. 1 (1988).

4. See generally David B. Wilkins, Making Context Count: Regulating Lawyers After Kaye, Scholer, 66 S. CAL. L. Rev. 1145 (1993). For the classic argument that the criminal defense context may be ethically distinct from the other work lawyers do, see Richard Wasserstrom, Lawyers as Professionals: Some Moral Issues, 5 Hum. RTS. 1, 6 (1975).

5. The unfolding controversy over the role that lawyers for both Bank of America and Merrill Lynch played in the failure to disclose to the shareholders of either company the billions of dollars in bonuses that Merrill intended to pay out prior to the merger of the two institutions may very well be just the opening salvo in this line of attack. See SEC Actions, http://www.secactions.com/?p=1430 (Aug. 25, 2009, 3:36 EST) (reporting that "[a]ccording to the SEC, it was the advice of the lawyers that resulted in the shareholders of both companies not being told about the billions of dollars in bonuses approved for Merrill employees when they voted on the acquisition of the broker by the bank"). If the blistering opinion by Judge Jed Rakoff rejecting the proposed settlement in the Bank of 
When they do, it is unlikely enforcement officials or the public will have much sympathy for an ethic that appears to command lawyers for these powerful clients to proceed "reckless of the consequences" even if it means casting "the country in confusion"-let alone bankruptcy. Given the current mood, there may be little the bar can do to avoid this "unhappy fate" this time around. But as we prepare to enter into a brave new world in which all corporate actors-lawyers included - will almost certainly face increased scrutiny, I want to suggest that the profession and those we purport to serve would do well to consider whether there is something more fundamentally wrong with applying Brougham's conception of the lawyer's role to the corporate context than the conflation of the standards of advocacy appropriate to the criminal context with those that should govern in civil or regulatory matters.

At the heart of Brougham's understanding of the lawyer's role stands a simple but powerful assumption: that the attorney-client relationship is essentially one of agency. Of course a lawyer "knows but one person in all the world" and is required to promote that person's interests "by all means and expedients and at all hazards and costs to other persons," even "to himself," Brougham would likely say. ${ }^{6}$ These are simply the duties that an agent owes to his or her principal. ${ }^{7}$ Lawyers are doing no more-and should be entitled to do no less - than others who are engaged by principals to protect their interests and pursue their goals. ${ }^{8}$

It is this traditional idea that I intend to question here. I do so in the spirit of another one of UCL's great founders, Jeremy Bentham, whose auto-icon I had the pleasure of communing with when I delivered this paper in UCL in March 2008. ${ }^{9}$

America/Merrill Lynch bonus case is any indication, the corporate bar could be in for a very bumpy ride indeed. See Zachery Kouwe, Judge Rejects a Settlement over Bonuses, N.Y. TIMES, Sept. 15, 2009, at A1 (reporting that "[g]iving voice to the anger and frustration of many ordinary Americans, Judge Jed S. Rakoff issued a scathing ruling" rejecting the settlement). On February 21, 2010, Judge Rakoff approved a $\$ 150$ million settlement, but nevertheless criticized the settlement heavily. See SEC v. Bank of Am. Corp., Nos. 09 Civ. 6829,10 Civ. 0215, slip op. at 14 (S.D.N.Y. Feb. 22, 2010) ("While better than nothing, this is half-baked justice at best.").

6. Freedman, supra note 1 , at 1215.

7. See L. Ray Patterson, Legal Ethics and the Lawyer's Duty of Loyalty, 29 EMORY L.J. 909, 913-14 (1980) (characterizing the attorney-client relationship as primarily constituted by agency law).

8. See Randolph E. Paul, The Lawyer as a Tax Adviser, 25 RockY MTN. L. REV. 412, 418 (1953) (arguing that "[t]he job entrusted to [the tax lawyer] by his client is to use all his learning and ability to protect his client's rights" and that the lawyer's "notions of policy, and his personal view of what the law should be, are irrelevant"). Indeed, since lawyers are not only "agents" but also "fiduciaries," their obligation to pursue the interests of their client-principals is arguably even stronger than agents who represent clients in more armslength contexts. For an account of the heightened obligations of fiduciaries who purport to act for their principals in situations of trust and confidence, see Tamar Frankel, Fiduciary Law, 71 CAL. L. REV. 795, 797-802 (1983).

9. Jeremy Bentham's "auto-icon" is in fact his own mummified remains, which are housed in a large plate-glass case in the Thane Library of Medical Sciences, University College London. For a full discussion of the creation of Bentham's auto-icon, see C. F. A. 
Throughout his life, Bentham wrote many brilliant commentaries on law and legal ethics. In 1827, he delivered an especially devastating critique of the social utility of the attorney-client privilege. Bentham argued that the privilege was both unnecessary to protect the innocent (since any good lawyer should be able to persuade an innocent person that giving the lawyer all the facts would increase the client's chance of being acquitted) and socially pernicious with respect to the guilty (who would not be candid with their lawyers and therefore receive less effective legal representation, thereby making it more likely that they would be convicted-which is exactly what society should want!). ${ }^{10}$ It is in the spirit of this skeptical gaze that I want to examine the traditional claim that the corporate attorneyclient relationship is best understood as being one of agency.

Specifically, I will argue that for all of its intuitive appeal, the agency model is no longer a helpful template for understanding the relationship between corporations and their outside firms. Instead, expanding on ideas that I first put forward in 1998, ${ }^{11}$ I will argue that the relationship between these large and sophisticated clients and their increasingly large and sophisticated outside counsel is better conceptualized as a new kind of strategic alliance or partnership_or, to borrow a phrase that has been used to describe the long-term strategic partnerships between Japanese automakers and their suppliers, a new kind of "legal keiretsu"12 - than as the typical agent-principal relationship envisioned by Brougham.

My claim is both descriptive and normative. Descriptively, after spending most of the 1980s and 1990s acquiring in-house expertise that allowed them to break apart the bilateral monopolies that traditionally characterized the relationship between companies and their primary outside law firm and moving toward a spot-contracting model for procuring legal services, a growing number of corporate clients have reversed course and dramatically reduced the number of law firms that they use, particularly for high-value work. At the same time, the law firms that serve these clients are consolidating as well-both through mergers and acquisitions of rival firms and by seeking new ways to consolidate and expand the work that they do for their best clients. As a result, clients and firms are increasingly entering into complex interdependent relationships that resemble the kind of

Marmoy, The "Auto-Icon" of Jeremy Bentham at University College, London, 2 MED. HIST. 77, 77-86 (1958), available at http://www.ncbi.nlm.nih.gov/pmc/articles/PMC1034365/ $\mathrm{pdf} / \mathrm{medhist} 00183-0005$.pdf. Bentham remained thoughtfully silent with respect to my thesis so he bears no responsibility for what follows.

10. 7 JEREMY BENTHAM, The Rationale of Judicial Evidence, in THE WORKS OF JEREMY BENTHAM 473-75, 477, 479 (John Bowring ed., London, Simpkin, Marshall \& Co. 1843).

11. See generally David B. Wilkins, Do Clients Have Ethical Obligations to Lawyers? Some Lessons from the Diversity Wars, 11 GEO. J. LEGAL ETHICS 855 (1998).

12. For a general background on keiretsu, see Ronald J. Gilson \& Mark J. Roe, Understanding the Japanese Keiretsu: Overlaps Between Corporate Governance and Industrial Organization, 102 YALE L.J. 871 (1993). 
strategic alliances that these same companies have entered into with many of their other suppliers. ${ }^{13}$

These changes, and the forces that have produced them, in turn raise important challenges for the legal profession's ability to fulfill its normative commitments to clients and to the public. Due in large measure to the growth of in-house legal departments, corporate clients today have a far greater ability to hold their lawyer-agents to full-throated standards of partisan advocacy than any client could have dreamed of during Brougham's day. Paradoxically, however, the spot-contracting model that exemplifies this new power often has failed to deliver the full range of benefits in terms of either quality or price that the in-house lawyers who led this charge believed that it would. This failure to deliver on the promise of market control has in turn led many of these clients to move from the "logic of power," which emphasizes the ability of stronger actors to gain by coercing their exchange partners into an asymmetric distribution of value, to a "logic of embeddedness," which emphasizes the importance of reciprocity and mutual trust for the production of joint gains. ${ }^{14}$ As a result, these companies and their primary firms are more likely to utilize strategies that emphasize "voice" rather than "exit" to resolve problems that arise during the relationship-although, as we will see, exit always remains a credible threat. ${ }^{15}$

This new logic, however, arguably threatens the ability of outside counsel to function as public-regarding gatekeepers. ${ }^{16}$ Although these concerns are legitimate, I will argue that the logic of embeddedness is no more corrosive of public-regarding values than the logic of power that now typifies the relationship between companies and their outside firms. Indeed, this logic has the potential to be significantly less corrosive-

13. For an excellent description and analysis of the characteristics of these increasingly important relationships, see Ronald J. Gilson, Charles F. Sabel \& Robert E. Scott, Contracting for Innovation: Vertical Disintegration and Interfirm Collaboration, 109 COLUM. L. REV. 431 (2009). I return to Gilson et al.'s analysis of the characterization of these relationships below.

14. See generally Ranjay Gulati \& Maxim Sytch, Dependence Asymmetry and Joint Dependence in Interorganizational Relationships: Effects of Embeddedness on $a$ Manufacturer's Performance in Procurement Relationships, 52 ADMIN. SCI. Q. 32 (2007) (discussing the difference between the "logic of power" and the "logic of embeddedness").

15. See Susan R. Helper \& Mari Sako, Supplier Relations in Japan and the United States: Are They Converging?, MIT SLOAN MGMT. REV., Spring 1995, at 77, 77-84 (discussing the difference between "voice" and "exit" strategies in customer-supplier relationships in the automobile industry). For the classic formulation of the difference between voice and exit, see ALBERT O. HIRSCHMAN, EXIT, VOICE, AND LOYALTY: RESPONSES TO DECLINES IN FIRMS, ORGANIZATIONS, AND STATES (1970).

16. Reinier Kraakman was the first to apply the term "gatekeeper" to describe this aspect of the lawyer's role and, more importantly, to explore the factors that influence whether lawyers will be able to play this role effectively. See Reinier H. Kraakman, Gatekeepers: The Anatomy of a Third-Party Enforcement Strategy, 2 J.L. ECON. \& ORG. 53 (1986); see also JoHn C. COFFEE, JR, GATEKEEPERS: ThE PROFESSIONS AND CORPORATE GovernanCE (2006). The idea that lawyers should be "officers of the court" with responsibilities to the public purposes of the law, however, is as old as the profession itself. See generally, e.g., Eugene R. Gaetke, Lawyers as Officers of the Court, 42 VAND. L. REV. 39 (1989). 
particularly if we move away from ethical and regulatory structures based on a principal-agent model that serves only to entrench the ability of powerful corporate-principals to impose their will on increasingly vulnerable lawyer-agents. Indeed as a wag like Bentham might say, current market conditions have largely turned the traditional justification for the agency model on its head. By withholding information and manipulating incentives, sophisticated corporate clients now have the power to pressure their lawyers into taking risky or unethical actions that threaten to throw their law firms "into confusion" in the form of legal peril or financial ruin. "Innocent" lawyers who do not want to participate in such actions have no recourse other than to resign-or be fired. At the same time, "guilty" lawyers who have no interest in standing up to client pressure are given a pass on the ground that they are not responsible for the ends of the representation and are required to follow the client's direction so long as it is technically within the letter of the law. A model of the attorney-client relationship that recognizes that both clients and lawyers have reciprocal obligations of disclosure, forbearance, and fair dealing of the kind characteristic of strategic alliances, I will argue, provides a better foundation for dealing with these increasingly important problems.

The rest of this Essay proceeds in five parts. Part I briefly sets out the traditional agency model of the attorney-client relationship and explores how that model has always been in tension with the claim that corporate lawyers should also act as gatekeepers who protect and promote public norms. Part II tracks the evolution of the corporate attorney-client relationship with respect to these two competing dimensions through three stages of development: the traditional Golden Age marriage, characterized by bilateral monopolies reinforced by information asymmetry between clients and lawyers and an oligopolistic cartel among firms; the divorce (circa 1989), typified by spot-contracting brought about by the growth of sophisticated in-house legal departments; and the development of what I will call a legal keiretsu, characterized by "convergence" of law firm relationships by companies, "consolidation" among firms, and integration and information exchange both within and across organizational boundaries, reinforced by a surprising amount of turnover among in-house lawyers. Part III then explores the implications of this third stage of development for clients, lawyers, and the public. Although there are risks for each of these constituencies in the hybrid model of cooperation and competition that characterizes the new logic of embeddedness that informs these new strategic alliances, there are also important benefits-benefits that arguably minimize the traditional tension between the client-service and gatekeeping parts of the corporate lawyer's role. These potential benefits, however, will only be realized if the public-regarding potential of these new legal keiretsus is reinforced by appropriate ethical and regulatory support. Part IV therefore begins the process of identifying ethical and regulatory changes that can promote the potential of these new strategic alliances while limiting their dangers. Part $\mathrm{V}$ concludes by briefly 
identifying questions for future research, particularly in light of the current economic crisis. Although I concede that the ultimate implications of the global slowdown for the relationship between large companies and their principal outside law firms have yet to be determined, initiatives such as the American Corporate Counsel Association's Value Challenge suggest that the new economic environment may very well accelerate the move toward the kind of partnering model I describe.

\section{CAN AGENTS BE GATEKEEPERS?}

Even at the time Lord Brougham uttered his famous paean to partisanship in 1820 , it was well established that the client-centered duties he celebrated did not comprise the full measure of the lawyer's role. In addition to being faithful agents who pursued their client's interests, lawyers have traditionally also been expected to be "officers of the court" who promote and uphold the public purposes of the legal framework. ${ }^{17}$ For most of the profession's history, the bar has portrayed these twin obligations as being entirely consistent and harmonious. Lawyers promote the public good, according to this standard view, by zealously advocating for the interests of their private clients "within the bounds of the law." 18

However, the public and, more specifically, enforcement officials have grown increasingly less sanguine about this alleged congruence. Beginning with a string of high profile enforcement actions in the 1970s, the Securities and Exchange Commission (SEC), for example, has pressed lawyers to take their public duties to investors more seriously when advising corporate clients on complying with federal securities laws. ${ }^{19}$ In the 1980 s and 1990s, the Internal Revenue Service (IRS) and the Office of Thrift Supervision joined the chorus, bringing multimillion dollar enforcement actions and law suits against prominent law firms for advocating too zealously on behalf of their corporate clients in a manner that contravened

17. See Gaetke, supra note 16, at 41-43. As Robert Gordon emphasizes, this ideal was inherited from the traditions of the English bar and has been a part of the legal profession's self-understanding since the 18th century. See generally Robert W. Gordon, "The Ideal and the Actual in the Law": Fantasies and Practices of New York City Lawyers, 1870-1910, in The New High Priests: Lawyers in Post-Civil War America 51, 51-74 (Gerard W. Gawalt ed., 1984).

18. The following statement in the old Model Code typifies this view: "The duty of a lawyer, both to his client and to the legal system, is to represent his client zealously within the bounds of the law." See MODEL CODE OF PROF'L RESPONSIBILITY EC 7-1 (1982) (footnotes omitted). The Model Rules adopted in 1983 take a much more nuanced view of this connection. Although claiming that "[a] lawyer's responsibilities as a representative of clients, an officer of the legal system and a public citizen are usually harmonious," the rules also concede that "[i]n the nature of law practice . . . conflicting responsibilities are encountered" among the lawyer's various duties "while [also] earning a satisfactory living." See MOdEl RULES OF PROF'L CONDUCT pmbl. (1983).

19. See CofFEE, supra note 16, at 202-16; Lewis D. Lowenfels, Expanding Public Responsibilities of Securities Lawyers: An Analysis of the New Trend in Standard of Care and Priorities of Duties, 74 CoLUM. L. REV. 412 (1974); L. Ray Patterson, The Limits of the Lawyer's Discretion and the Law of Legal Ethics: National Student Marketing Revisited, 1979 DUKE L.J. 1251. 
applicable legal constraints. ${ }^{20}$ Although prosecutions against lawyers in the wake of Enron and other related corporate scandals in 2001 have been less numerous - and, it should be noted, less successful - there is nevertheless a growing consensus that it is no longer plausible to assume that the private interests of corporate clients will always, or even usually, be congruent with the public purposes of the legal framework, or that reputational incentives alone will always be sufficient to bridge this divide. ${ }^{21}$

Coming up with viable means for reinvigorating the lawyer's gatekeeping role, however, has proven to be substantially more illusiveand controversial. Reformers have tended to concentrate on two strategies: normative strategies designed to remind lawyers that they do in fact have duties to the legal framework that are as, if not more, important than their private duties to clients, and enforcement strategies that hold lawyers accountable for assisting-or in some cases for not preventing-client misconduct. ${ }^{22}$ Both of these strategies have achieved important resultsindeed, I have advocated both in the past and will do so again here. But with few exceptions, those who have advocated these strategies have done so without challenging the underlying characterization of the lawyer-client relationship as grounded in the principles of agency law that arguably has helped to create the tension between the lawyer's private and public duties in the first instance. ${ }^{23}$

It is hardly surprising that the agency model has remained strong, even as Brougham's overzealous characterization of it has lost favor. Clients, after all, hire lawyers to pursue their projects in their name and on their behalf. In addition, clients are generally held accountable for their lawyer's conduct. $^{24}$ Given these background characteristics, it is difficult to conceive of a plausible account of the attorney-client relationship that does not view the lawyer in some significant sense as the client's agent.

Nevertheless, the reality of the corporate attorney-client relationship has always been more complex than the simple agency model would suggest. To be sure, corporations have always tried to ensure that outside counsel

20. See COFFEE, supra note 16 , at $213-15$.

21. See id. at 4 \& n.9 (criticizing Judge Frank H. Easterbrook for assuming that reputational concerns will automatically make gatekeepers such as lawyers conform to public norms).

22. For an example of a strategy that relies on changing the norms of legal practice, see William H. Simon, Ethical Discretion in Lawyering, 101 HARV. L. REv. 1083 (1988). See also Gordon, supra note 3. My own prior work has tended to emphasize enforcement. See generally, e.g., David B. Wilkins, Who Should Regulate Lawyers?, 105 HARV. L. REV. 799 (1992) (arguing for promoting public-regarding gatekeeping by increasing enforcement of existing public duties).

23. David Luban has been one such exception. See LUBAN, supra note 3, at 324-26 (arguing that the relationship between public interest lawyers and their clients is better understood as one between "political comrades" than one of agency).

24. See, e.g., Link v. Wabash R.R. Co., 370 U.S. 626, 634 (1962) ("[E]ach party is deemed bound by the acts of his lawyer-agent and is considered to have "notice of all facts, notice of which can be charged upon the attorney." (quoting Smith v. Ayer, 101 U.S. 320, $326(1879))$ ). 
follow their instructions and deliver high quality legal services that advance the company's objectives. And law firms have always worked hard at least to appear to be satisfying these expectations. But since Paul Cravath and his partners first put together the prototype of the modern large law firm in the waning decades of the 19th century, the actual balance of authority and decisionmaking responsibility between companies and their outside counsel has departed significantly from the standard agency account. Elite lawyers never conceived of themselves, to borrow Anthony Kronman's pejorative but nevertheless evocative phrase, as "deferential servants" who merely carry out the client's bidding. ${ }^{25}$ Instead, these early lawyers aspired to be wise counselors, or "lawyer-statesmen" to borrow another Kronman phrase, who played a key role in shaping their clients' goals and in mediating between these private ends and the public purposes of the legal framework. ${ }^{26}$ By the so-called "Golden Age" of the large law firm in the middle decades of the 20th century, this "Whiggish ideology" had become the accepted understanding of the corporate lawyer's role. ${ }^{27}$

In the next part, I will explore how market conditions in the last decades of the 20th century made it increasingly difficult for lawyers to play this gatekeeping role- to the extent that they were actually serving this function before. ${ }^{28}$ For present purposes, however, I want to highlight how the agency model has contributed to this decline. By characterizing the relationship between corporate lawyers and their clients as fundamentally one of agency, the standard account systematically marginalizes, and indeed delegitimizes, a lawyer's allegiance to this broader public role. Rather than being viewed as "trusted advisors" who help to shape their clients" objectives in ways that ultimately serve both the clients' and the public's long-term goals, lawyers who seek to influence client ends are chastised as "moral policemen" who constrain their clients' "first class citizenship" by "arrogating to themselves" decisionmaking authority that should belong exclusively to their client-principals. ${ }^{29}$ The result has been an increasing tendency among even the most public-regarding segments of the corporate bar to embrace what Robert Gordon calls "schizoid lawyering" in which

25. See Anthony T. Kronman, The Lost Lawyer: Failing Ideals of the Legal PROFESSION 15 (1993).

26. $I d$.

27. See Erwin O. Smigel, The Wall Street lawyer: Professional Organization MAN? 343-44 (1964). For the connection between this account of lawyer professionalism and the noblesse oblige traditions of the early Whig party, see Gordon, supra note 17 . The scare quotes around "Golden Age," as Marc Galanter wryly notes, are to remind us that the period in question was only golden for those with the right race, gender, and religion to be admitted to the club. See Marc Galanter, Lawyers in the Mist: The Golden Age of Legal Nostalgia, 100 Dick. L. REv. 549, 555 \& n.28 (1996). I have made a similar critique of Kronman. See David B. Wilkins, Practical Wisdom for Practicing Lawyers: Separating Ideals from Ideology in Legal Ethics, 108 HARV. L. REv. 458 (1995) (book review).

28. See Gordon, supra note 17 (acknowledging that lawyers have probably never lived up to their stated ideals about professional independence, but citing examples in which the bar promoted projects that were not in the short-term interests of their corporate clientele).

29. See generally, e.g., Stephen L. Pepper, The Lawyer's Amoral Ethical Role: A Defense, A Problem, and Some Possibilities, 1986 AM. B. FOUND. RES. J. 613. 
practitioners confine their public commitments to their own (increasingly scarce) private time, while accepting uncritically the instructions of their private clients unmediated by any attention to public ends. ${ }^{30}$

Moreover, as I argued in 1998, "the agency model of the lawyer's role assumes that all ethical obligations flow from the lawyer-agent to the clientprincipal." 31 Clients have only rights, not obligations. ${ }^{32}$ To be sure, these rights may be limited by a lawyer's correlative obligations to the legal framework and, on occasion, even by "the lawyer's own interest in remaining an upright person while earning a satisfactory living." 33 As important and as controversial as these limitations may be, however, they do not disturb the basic framework in which clients have no obligations, save for their duty to pay for the services they receive. ${ }^{34}$ As corporate clients have become increasingly sophisticated about their legal needs and interests - and increasingly capable of pressing their outside counsel to pursue these self-defined ends - the inattention to the obligations of clients sanctioned by the agency model has made it increasingly difficult to conceive of a plausible gatekeeping role for lawyers.

Before we proclaim the lawyer-statesman lost forever, however, it is important to remember that market conditions are by their very nature dynamic. In recent years, these conditions have been shifting back in the direction of a more collaborative relationship between companies and law firms. Understanding this shift, I will argue, highlights the need for a corresponding reinterpretation of the way in which we conceive of the normative obligations of both lawyers and clients.

\section{FROM SPOUSES TO VENDORS TO PARTNERS}

Over the last century the corporate attorney-client relationship has gone through three distinct, albeit overlapping, phases. The following sections present a stylized description of each of these periods. ${ }^{35}$ Although important elements of the agency model are presented in all three, none

30. Gordon, supra note 3, at 22-23.

31. See Wilkins, supra note 11 , at $855-56$.

32. See L. Ray Patterson, The Function of a Code of Legal Ethics, 35 U. MIAMI L. REv. 695, 699-700 (1981) (arguing that the Model Code implies "that lawyers have only duties (not rights) in relation to clients, and that clients have only rights (not duties) in relation to lawyers"). Patterson goes on to argue against this understanding. Id.

33. MODEL RULES OF PROF'L CONDUCT pmbl. (1983).

34. See Wilkins, supra note 11, at 855-56 (discussing the limited duties that clientprincipals owe to their lawyer-agents).

35. It is important to note that each of these periods is more complex than these simple synopses suggest. Specifically, in each period particular companies and law firms deviated from the general tendencies I describe in some, or in some cases all, of their respective attorney-client relationships. This is particularly true, as I note below, of what I have characterized as the "divorce" period in which even ardent advocates of breaking apart the bilateral monopolies that characterized the earlier period also recognized the value of "partnering" with their most important outside firms on their most important matters. Notwithstanding this important gloss, however, most knowledgeable observers would concede that the overall ethos of this period was to move toward a spot-contracting model of the attorney-client relationship characterized by the mantra that "we hire lawyers not firms." 
conforms to the underlying assumptions upon which Lord Brougham's fullthroated defense of the lawyer-as-agent model was based.

\section{A. The Marriage: The Trusted - and Unaccountable-Advisor}

As indicated above, corporate lawyers have always sought to be more than simply agents to their powerful clients. Instead, Wall Street lawyers and their counterparts in other cities fashioned a role for themselves as trusted advisors who would guide their clients through the complex web of problems at the intersection of law and business. As legal historian Robert Gordon explains, although "[n]ominally representing . . . corporations, banking houses, or committees of security holders in bankruptcy proceedings," this new breed of practitioners "invented for themselves liaison roles in building or rebuilding the financial structures of American corporations that ensured the prosperity of the largest New York City law firms and came to seem indispensable to their clients." ${ }^{36}$

As a result, companies and their principal law firms developed deep and enduring relationships that extended to every aspect of the company's business. Until well into the 1960s, it was not uncommon, for example, for a single law firm to handle all of the legal business for its major clientsfrom slip and fall cases to "bet the company" litigation (to the extent such cases existed during this period) and important acquisitions or other structuring transactions. ${ }^{37}$ Indeed, many law firms were located in the same buildings that housed the offices of their primary client, typically a bank, and it was not at all unusual for these long-standing business ties to be cemented through personal friendships and even marriages.

As Ronald Gilson argues, however, there were factors other than social ties that helped to perpetuate this state of affairs. In addition to the glue that undoubtedly comes from being members of the same small elite circle, the deep and enduring relationships between corporations and their outside counsel were also reinforced by pervasive information asymmetries between even the largest company and their outside counsel. ${ }^{38}$ Beginning with the New Deal and accelerating through the "rights revolution" of the 1960 s, the law governing corporate conduct became increasingly complex, subjecting corporations to a bewildering array of new regulations and potential liabilities. Few businesses, however, had any significant internal expertise to help them decipher and navigate these new legal risks. As a result, even sophisticated business executives were likely to defer to outside

36. Gordon, supra note 17 , at 59 (citing 1 ROBERT T. SWAINE, THE CRAVATH FIRM AND ITS PREDECESSORS 1819-1947, at 369-71 (1948); HENRY W. TAFT, A CENTURY AND A HALF OF THE NEW YORK BAR 191-201 (1938)).

37. See Marc Galanter \& ThOmas Palay, Tournament of Lawyers: The TRANSFORMATION OF THE BIG LAW FIRM 34 (1991) (describing the enduring relationship between companies and firms during the "Golden Age" and quoting clients as stating that "outside counsel has been with us for many, many years" or that they "have never given any thought to hiring another" firm).

38. See generally Ronald J. Gilson, The Devolution of the Legal Profession: A Demand Side Perspective, 49 MD. L. REV. 869 (1990). 
counsel to assess the company's legal risks and to define and implement an appropriate legal strategy. ${ }^{39}$

Given these information gaps, Gilson concludes, corporations traditionally found it efficient to invest in long-term relationships with a full-service outside firm that acted as both "diagnostician" of the client's legal needs and as reliable "referring agents" (often to another member of the same law firm) to ensure that the client's problems were handled correctly. These long-term relationships, in turn, created economic disincentives to lawyer switching that gave lawyers de facto power over even the largest corporate clients. ${ }^{40}$

To these structural aspects of the attorney-client relationship during the Golden Age, Robert Gordon adds an important normative dimension. ${ }^{41}$. In addition to their superior knowledge of the law and long-term client relationships that discouraged switching, lawyers during the Golden Age had the added advantage of the widespread belief among both lawyers and clients in the autonomy of law itself. Notwithstanding the "legal realist" critique raised by left-leaning law professors in the 1930s, law schools, courts, lawmakers, and popular culture spoke of law primarily as a set of formal rules separate and distinct from politics or even morality.

During the Golden Age, lawyers used this power in a variety of ways. Some of these ways undoubtedly benefited their corporate clients and were therefore consistent with the spirit of the agency model. The long-standing relationships between senior partners and corporate CEOs, for example, undoubtedly allowed the former to gain in-depth knowledge of the latter's business and to counsel the company in a manner consistent with its overall strategy and goals. At the same time, precisely because they were located in independent firms, these trusted advisors were also able to give their clients the benefit of their experience gained from representing other clients with similar problems. ${ }^{42}$

In addition, the stability of these lawyer-client relationships also helped to ensure that the valuable knowledge accumulated by senior lawyers would be passed on to the next generation. Clients were literally passed down from senior partners to their most promising protégé-who had already worked on the client's matters for several years before assuming their new role. ${ }^{43}$ Even junior associates were likely to be well trained, both in the particulars of the client's work, having worked on a variety of problems under the close supervision of more senior lawyers, and more generally in the broad range of legal problems a client might confront, having rotated

39. Id.

40. GALANTER \& Palay, supra note 37 , at 34-36.

41. See generally Gordon, supra note 3.

42. See SMIGEL, supra note 27 , at 343-44 (arguing that as the law governing corporate conduct "proliferated and increased in importance" corporate clients increasingly valued firms with the experience to interpret the new legal order).

43. Id. at 107-08 (describing how "chosen" associates "are treated like heirs" and groomed to take over the firm's important client relationships). 
through the various areas of the firm's practice before settling into a particular specialty. ${ }^{44}$

These same structural and attitudinal features of the lawyer-client relationship between companies and firms during the Golden Age, however, also increased the ability of law firms to act as gatekeepers. As Professor Gilson argues, high switching costs allow lawyers to "shelter[] the . . . gatekeeping function from the pressure of client demand." 45 Even if a company knew that it disagreed with the advice given by outside counsel, it would still have to choose to incur both the cost of bringing another law firm up to speed and the loss of the relationship-specific capital of its prior counsel if it decided to move work from one law firm to another. Although some companies were willing to bear this expense, many others undoubtedly simply agreed to follow their original lawyer's advice, even if at some level corporate managers would have preferred to pursue other options. The fact that even Golden Age law firms had large enough client portfolios to ensure that "no one client provide[s] enough income to materially or consciously influence the law office's legal opinion" also helped to ensure that firms were well positioned to see themselves as "'represent[ing]' the law" with a duty to "separate themselves from the client." 46

From the perspective of the lawyer's role as an officer of the court entrusted with safeguarding the administration of justice, the fact that law firms in the Golden Age were well positioned to constrain arguably harmful client conduct by exerting their market power is a good thing. From the perspective of the agency model, however, this result is significantly more problematic. If, as Lord Brougham argued, an advocate should know "only one person in the world" and pursue that client's interests single-mindedly, even if it risks "throwing the country into confusion," then anything short of counseling a client to engage in conduct that is clearly criminal or fraudulent should be a required part of the agent's role. ${ }^{47}$ To be sure, lawyers during the Golden Age continued to assert that there was in fact no conflict between these two positions. "Independent legal opinion," as Erwin Smigel glowingly reported, "is perhaps the commodity [law firms] offer, and the primary commodity for which they are paid." 48 As these

44. Id. at 52 (describing how law firms regarded the "practice of law in the early years in the nature of an internship" and promised to provide young associates with both "broad general experience" as well as specific grounding in the problems of particular clients).

45. Gilson, supra note 38 , at 899.

46. SMIGEL, supra note 27 , at 344.

47. See generally, e.g., Pepper, supra note 29 (advocating this position). The constraint that a lawyer may not "counsel . . . or assist a client, in conduct that the lawyer knows is criminal or fraudulent" comes from MODEL RULES OF PROF'L CONDUCT R. 1.2(d) (1983). Revealingly, Stephen Pepper argues that in order to maximize the autonomy of clientprincipals, lawyers should be required to construe even this standard constraint narrowly by giving clients access to the lawyer's "legal realist" understanding of the law as little more than the price of the sanction discounted by the probability of enforcement. Pepper, supra note 29 , at $624-28$.

48. SMIGEL, supra note 27, at 343. 
halcyon days for law firms drew to a close, however, it became increasingly clear that many corporate clients did not share the view that public gatekeeping duties were entirely congruent with their rights as principals to control the scope and direction of the representation.

Moreover, as legal costs continued to skyrocket, many corporate clients began to suspect that their "trusted advisors" were engaged in violations of their agency duties that extended far beyond failing to push to (or beyond) the limits of the law. Whether these clients looked at staffing decisions (increasingly large teams of lawyers being thrown against every new problem), wasteful or duplicative effort (associates writing extensive memos to the file on problems that might never arise or having to review basic facts every time a new lawyer joined the team), or downright price gouging ( $\$ 1$ a page for Xeroxing or first class travel at the client's expense), companies began to feel that firms were using their market power to pad the partners' pockets at their expense. Given these discoveries, the traditional one-line bill "for services rendered" no longer seemed very appealing.

Indeed, many clients began to notice that their once staid law firms were taking on a distinctly entrepreneurial tone. Law firms grew rapidly in both size and scope during the 1970s and 1980s. At the same time, these institutions shed many of the gentlemanly norms that had traditionally governed relations among these institutions and began openly and aggressively competing for both talent and clients. ${ }^{49}$

Clients, in turn, both reacted to-and helped to spur-these developments by aggressively seeking ways to reduce their steadily escalating legal bills. As with many necessary but expensive services, a growing number decided that it would be cheaper to "make" legal services internally rather than to "buy" them on the open market.

\section{B. The Divorce: "We Hire Lawyers Not Firms"}

By 1990 when Gilson chronicled the market inefficiencies that allowed lawyers during the Golden Age to act as gatekeepers with respect to their corporate clients, it was already apparent that the cozy relationships that facilitated this phenomenon were going the way of the dinosaur. Throughout the 1980s corporate clients moved aggressively to close each of the three major information asymmetries that rendered them vulnerable to strategic manipulation-whether for benign purposes or otherwise-by their outside lawyers. The mechanism by which clients have accomplished this goal is simple. Instead of relying on outside firms to meet their diagnostic and referral needs, corporations began internalizing these functions by building sophisticated and extensive in-house legal staffs. ${ }^{50}$ The result, as Gilson observed in 1990, has been "a dramatic reduction in

49. See Galanter \& Palay, supra note 37 , at 52-59.

50. See Robert Eli Rosen, The Inside Counsel Movement, Professional Judgment and Organizational Representation, 64 IND. L.J. 479, 483-84 (1989). 
the switching costs facing clients and an elimination of lawyers' market power." 51

If Paul Cravath has become the public exemplar of the law firm as trusted advisor, then the General Electric Company's (GE) long-time chief legal officer Ben Heineman is the symbol of the modern general counsel who helped to unravel the close connection between law firms and corporate clients that Cravath pioneered. ${ }^{52}$ When Heineman took over the legal department at GE in 1989, he moved systematically to break up the longstanding relationships that the company traditionally maintained with its principal law firms. Working with the express blessing of GE's legendary CEO Jack Welch, ${ }^{53}$ Heineman recruited a cadre of talented lawyers from prestigious law firms to work in GE's legal department and then charged them with seeking out and eliminating unnecessary legal costs while improving the quality of the services the company received. By the conclusion of Heineman's tenure as General Counsel in 2006, GE had over 1000 lawyers in its legal department-enough to rank it among the twenty largest law firms in size if it had been a freestanding entity. These lawyers, in turn, substantially altered the relationship between inside and outside counsel and their respective roles in providing legal services to large companies.

Specifically, in-house counsel at GE, and the many companies that began to emulate its policies, took over much of the work that had previously been

51. See Gilson, supra note 38, at 903.

52. The banner headline over the cover story in Corporate Counsel magazine in which Heineman describes his role during this period captures this pride of place: "In the Beginning." See Ben W. Heineman, Jr., In the Beginning, CoRP. Couns., Apr. 2006, at 84, 84-89. In the interest of full disclosure, Heineman is a Senior Distinguished Fellow at the Harvard Law School Program on the Legal Profession. It is precisely because of this affiliation that I am particularly grateful for his graciousness in response to my decision to use him as the stylized exemplar of the tendency among general counsel during this period to move toward a more spot-contracting model of the attorney-client relationship. As Heineman has made clear in our conversations about this project, GE always believed in partnering with its outside counsel on important matters and that most of the company's relationships with its primary outside firms were both collegial and productive. I have no doubt that this is true, as it undoubtedly was for many other companies and firms. However, as Heineman also concedes, the locus of these relationships was at the level of the "matter" and not the "firm"- and that the company's primary goal was to secure the best lawyer for the work regardless of where that lawyer was housed, whether inside GE's legal department or in a firm that the company may or may not have used before. It is this emphasis on finding the best "horse for the course" that I believe characterizes the dominant ethos of this period.

53. As Heineman emphasized in an e-mail communication to me, business leaders play a crucial role in determining the nature and scope of a company's relationship to its lawyersboth inside counsel and outside firms. "Inside counsel really are much, much more concerned about their relationship with the Business than they are with outside counsel," he notes. The fact that Welch wanted lawyers who were intimately familiar with GE's culture and practices provided the key motivation for growing the company's in-house capacity. See E-mail from Ben W. Heineman, Jr. to author (Apr. 16, 2009) (on file with author). I return below to why business leaders might also want their outside counsel to have this kind of familiarity and how this is affecting the creation of a new relationship between companies and firms. 
sent to outside lawyers while also taking control over the process by which legal work that continued to go to firms was sourced, priced, and managed. ${ }^{54}$ Law firms were made to compete for work in "beauty contests" or "bake offs" in which the winners were required to reduce their normal fees and to consent to exacting supervision over virtually every aspect of the services to be performed. ${ }^{55}$ Not surprisingly, GE was the company that took this trend to its logical limit when in 2003 its subsidiary GE Commercial Finance required firms to compete in online auctions for the company's legal work. 56

When competing for this work, a law firm's prior relationship with the company was expressly discounted. Instead, general counsel sought to break up existing relationships by requiring firms to compete for every new piece of significant business and choosing the winner based on some combination of price and perceived expertise of the particular lawyers who would be working on the matter. "We hire lawyers, not firms" became the rallying cry of the day, with long-standing relationships with outside firms relegated to the graveyard of history. .7

This shift in emphasis between the lawyer and the firm both reflected and helped to spur the transformation of many large law firms from the relatively sleepy professional enclaves of the Golden Age to the twenty-first century cut-throat competitive businesses that these institutions have now become. These changes are familiar to anyone with even a passing interest in the legal profession, and I will only briefly recount them here. ${ }^{58}$ Suffice it to say that as competition for clients intensified, many firms began to compete aggressively for lawyers as well. Traditional taboos against lateral hiring of associates-and eventually partners-were discarded as firms moved to poach talented lawyers from their competitors, lawyers who were expected to bring their clients with them in tow. As more and more firms competed to hire the relatively static number of graduates from elite law schools, while trying to lure away "star" associates, partners, and even whole practice groups from competitors, compensation levels soared,

54. See generally Mary C. Daly, The Cultural, Ethical, and Legal Challenges in Lawyering for a Global Organization: The Role of the General Counsel, 46 EMORY L.J. 1057 (1997).

55. See, e.g., Robert L. Nelson, Partners with Power: The Social Transformation of the LARGE LAW Firm 57-59 (1988); Abram Chayes \& Antonia $\mathrm{H}$. Chayes, Corporate Counsel and the Elite Law Firm, 37 STAN. L. REV. 277, 278 (1985).

56. See Anthony Lin, Like Any Vendor, Law Firms Are Asked To Compete for Business on the Web, N.Y.L.J., Nov. 6, 2003, at 1.

57. See, e.g., Daniel J. DiLucchio, 'We Hire the Lawyer, Not the Law Firm'-Really?, LEGAL INTELLIGENCER, Jan. 29, 2009, http://www.law.com/jsp/pa/PubArticlePA.jsp?id= $1202427822427 \&$ slreturn=1\&hbxlogin=1 (noting that " $[t]$ his statement has been used for years, and will probably continue to be used" since "[t]his is what the general counsel want you to believe"). As DiLucchio's use of "Really?" at the end of his title implies, he is skeptical about whether this oft-repeated claim is in fact true. I return to his skepticism below.

58. For a catalogue of these familiar changes during the period between 1975 and 1995 ,

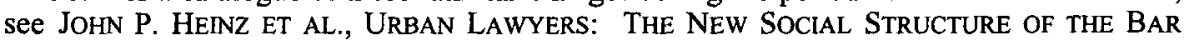
(2005). 
especially for "rainmaking" partners believed to control important client relationships. Firms that either did not or could not compete risked losing lawyers and clients and, as the century drew to a close, their very existence.

Collectively, these changes have substantially altered the value proposition that law firms made to their corporate clients. Rather than being "wise counselors" capable of guiding clients through the complex intersection of business strategy and legal rules, outside lawyers increasingly marketed (and I use the word advisedly) themselves as specialists capable of deploying large numbers of highly skilled experts at a moment's notice to handle the kind of emergencies that remain difficult for in-house lawyers to handle effectively. ${ }^{59}$ The value proposition offered to associates and partners considering joining firms shifted as well. Rather than traditional incentives such as hands-on training, a reasonable (albeit never certain) chance for partnership, and collegiality, firms relied on money and prestige to entice law students and lawyers to join their organizations and to compete to win the tournament of lawyers. ${ }^{60}$

Finally, in addition to breaking up the bilateral monopolies between companies and firms, general counsel sought to bifurcate the two parts of the lawyer's role as well. On the one hand, corporate counsel sought to justify their importance to their clients on the ground that in their role as sophisticated diagnosticians and purchasing agents, in-house lawyers were able to ensure that the conduct of outside counsel in fact closely approximated the agency model's ideal of a perfect congruence between the principal's interests and the agent's actions. In a competitive market filled with sophisticated repeat players, the argument went, outside firms have little incentive to fail to seek their client's objectives. Although these firms undoubtedly would prefer to extract the highest possible price in return, these same market conditions suggest that in the vast majority of cases, firms that significantly overcharge their clients will not be able to escape detection for very long. ${ }^{61}$

On the other hand, general counsel argued that they were now better situated than outside counsel to play the wise-counselor and gatekeeping roles that law firms, because of the episodic and distant nature of their dealings with companies, were no longer in a position to play. Far from signaling their lack of independence (as law firm partners had traditionally claimed), ${ }^{62}$ general counsel argued that their location inside the corporate

59. See KRONMAN, supra note 25 , at $271-314$.

60 . For an extended discussion of the changing incentives for associates and partners during this period, see David B. Wilkins \& G. Mitu Gulati, Reconceiving the Tournament of Lawyers: Tracking, Seeding, and Information Control in the Internal Labor Markets of Elite Law Firms, 84 VA. L. REV. 1581 (1998).

61. See Wilkins, supra note 22 , at $824-25$.

62. Rosen, supra note 50 , at 479 (noting corporate counsel were once referred to as "house counsel," "tame," and "kept lawyers"); see also Chayes \& Chayes, supra note 55, at 277 (noting that in-house counsel was typically a "relatively minor management figure, stereotypically a lawyer from the corporation's principal outside law firm who had not quite made the grade as partner"). 
hierarchy enabled them both to understand the client's business and to engage in risk assessment and preventative counseling more effectively than lawyers in outside firms. General counsel were therefore the lawyers who should be entrusted with the role of being both a "partner" to the business in achieving its objectives and the "guardian" of the company's long-term reputation and values. ${ }^{63}$

By the turn of the new century, this "inside counsel movement," as Robert Rosen has accurately labeled the push for authority and professional recognition by general counsel, appeared to have carried the day. General counsel in the model of Ben Heineman -indeed many were literally Heineman's protégés-occupied important positions in virtually every major company in the United States, and a growing number outside of the United States as well. ${ }^{64}$ Outside counsel typically report to the general counsel and are dependent upon these inside lawyers for crucial information about the client's goals. Indeed, it is fair to say that the general counsel has become the client of the outside law firm-leaving the top business people to be represented by in-house lawyers. ${ }^{65}$ As a result, even critics who believe that outside firms can no longer act as "lawyer-statesmen" hold out hope that in-house counsel will in fact fulfill the "guardian" role that law firms have largely vacated. 66

But a funny thing happened on the way to the coronation. Notwithstanding a significant investment in building up in-house capacities, many companies discovered that their outside spending on law firms continued to escalate throughout the 1990s and into the first decade of the twenty-first century. ${ }^{67}$ Nor were all of the resources being devoted to monitoring and controlling law firms resulting in increased levels of client satisfaction. ${ }^{68}$ Finally, in the wake of the Enron-related scandals in 2001, companies found themselves facing a new and more challenging regulatory environment in which enforcement officials were increasingly skeptical about the ability of corporate officers to detect and deter misconduct by their peers.

63. Not surprisingly, Ben Heineman has been the most vocal and articulate spokesperson for this view. See Ben W. Heineman, Jr., Caught in the Middle, CORP. Couns., Apr. 2007, at 84, 84-89 (arguing that general counsel must be both "partners" and "guardians").

64. See Deborah A. DeMott, The Discrete Roles of General Counsel, 74 Fordham L. REV. 955, 960-61 (2005).

65. See Nelson, supra note 55 , at 58.

66. See KronmAn, supra note 25 , at 283-84 (speculating that in-house lawyers may be able to carry on the lawyer-statesman ideal that outside counsel are no longer capable of performing).

67. See Gina Passarella, Corporate Law Departments Hiring More and Spending More, Legal INTELligenCER, Sept. 27, 2006, http://www.law.com/jsp/ihc/PubArticleIHC.jsp?id= 1159261524562 (reporting a survey by the consulting firm Altman \& Weil finding an average growth in outside legal expenses of $5.5 \%$ among responding companies notwithstanding a $19 \%$ increase in hiring in-house lawyers).

68. Janet L. Conley, GCs 'Can't Get No Satisfaction' from Outside Counsel, GC S., Mar. 2006, http://www.law.com/jsp/PubArticle.jsp?id=900005449198 (reporting a senior consultant from BTI as stating that "[s]atisfaction with outside law firms is 'particularly low" right now"). 
As a result, a growing number of companies have begun to rethink whether a spot-contracting model that simultaneously nuthlessly applies the agency model to outside firms while leaving all gatekeeping duties to inhouse counsel is the most effective way to meet their legal needs. Although it is too early to say whether the movement to reevaluate the Heineman bargain will result in as radical a restructuring of the relationship between companies and law firms as the one Heineman himself helped to introduce, there is enough evidence that an important change is underway to begin asking the question what such a new relationship might look like.

\section{A New Partnership?}

Five interlocking trends appear to be reshaping the relationship between corporate clients and their outside firms: "convergence" in the number of law firms a company is likely to hire (at least for important work); "consolidation" in the market for law firms capable of handling these kinds of assignments; "integration" of personnel, systems, and functions between clients and firms; "corporate redesign" to replace top-down hierarchy with teams comprised of both inside and outside consultants; and a new kind of inside counsel "movement" that is reshuffling the ranks of corporate general counsel. Collectively, these trends signal an important shift from spot contracting to a new partnership between clients and firms.

\section{Convergence}

Beginning in the mid-1990s, a growing number of companies have begun to dramatically reduce the number of outside firms to whom they give a significant percentage of their work. DuPont Chemical Corporation was among the first to move in this direction.

Like most large companies, DuPont spent most of the 1970s and 1980s diversifying its outside counsel while steadily beefing up its in-house legal department. But beginning in the $1990 \mathrm{~s}$, the company moved dramatically in the opposite direction. In just two years, DuPont reduced the number of U.S. law firms to whom it gave significant business from 350 to 35.69 Two of the company's in-house lawyers explained the reasons behind the company's change of heart in an article detailing a similar move in 2001 to reduce the number of firms that DuPont used for patent and trademark work internationally. Like most in-house lawyers raised on the spot-contracting model, the lawyers concede that they initially "subscribed to the common wisdom . . . that competition between firms in the same country worked to our advantage in terms of fees and service."70 As a result, by the late 1990s the company had more than 300 outside firms handling its international patent and trademark work, in addition to sixty in-house lawyers and paralegals whose job it was to monitor their performance. But after

69. See John Gibeaut, The Outside Looking In, 90 A.B.A. J. 46, 49 (2004).

70. John E. Dull \& David J. Gould, DuPont's Legal Experiment, IP WORLDWIDE, Nov. 25,2002 , http://www.law.com/jsp/article.jsp?id= $=900005533284$. 
engaging an outside consultant, the lawyers realized that this arrangement ended up raising, rather than reducing, the company's legal costs. As the lawyers explained,

[S]preading patent and trademark work among a large number of firms limited rather than strengthened our bargaining power. Firms receiving a relatively small amount of work, even from a perceived "prestigious" client, were not inclined to offer discounts or give close management attention to the work. ... Dealing with nearly 300 firms [also] made it difficult for the DuPont clerical staff to establish efficient internal procedures. Our bill paying practices were inconsistent and jeopardizing relationships. ${ }^{71}$

Worse yet, the lawyers came to believe that it also reduced the quality of the legal services the company received. "[W]e learned that the firms had little incentive to cooperate with one another on our behalf by sharing information and collaborating," the lawyers complained. ${ }^{72}$ "We needed to develop closer working relationships with all firms, not just the key ones, to ensure a good understanding of our business and IP strategies." 73

To move beyond these difficulties, the international group implemented a "convergence" program that was even more radical than the one that DuPont had gone through with respect to its U.S. firms. In less than a year, the company reduced the number of firms handling its international work in this area from 300 to 48 , with 28 of these handling more than $95 \%$ of the company's international patent and trademark work. ${ }^{74}$

During the last decade, a growing number of companies have followed the DuPont model. ${ }^{75}$ In a survey of corporate general counsel my colleagues and I conducted at Harvard Law School, ${ }^{76}$ for example, as of

71. Id.

72. Id.

73. Id.

74. Id.

75. See Libby Sander, In-House and Outside Counsel: Building a Solid Relationship, CHI. LAW., Mar. 2006, at 29 (citing several examples of convergence, including Allstate reducing its outside firms from $300-400$ to 13 firms that would handle $80 \%$ to $90 \%$ of the company's 'work). Even those skeptical of the value of convergence concede that it is a growing trend among companies. See Rees W. Morrison, Put Eggs in One Basket?, LeGAL TIMES (Wash., D.C.), Mar. 20, 2006, at 42 (acknowledging that "[f]or law departments in the past decade, convergence-that is, consolidating the number of outside firms used in order to save money - has been all the rage"). I will return to some of Morrison's criticisms below, but it is worth noting that even he advises a company to "concentrate".its legal spending by "lavish[ing] 80 percent of its outside-counsel budget on 10 percent of its law firms"). Id. For present purposes, the difference between "concentration" and "convergence" is largely semantic with respect to the firms getting the $80 \%$.

76. In 2006, a group of scholars affiliated with the Harvard Law School Center on Lawyers and the Professional Services Industry conducted a study of how large, publicly traded companies purchase legal services. Our data includes (1) detailed interviews with forty-three general counsel of Standard \& Poor's (S\&P) 500 corporations and (2) a survey sent to CLOs of all S\&P 500 companies as of December 31, 2006, which elicited a $28 \%$ response rate $(n=139)$, for a total sample (interview and survey) of 166 companies, representing a third of the entire S\&P 500. The survey respondents' companies accounted for between $30 \%$ to $40 \%$ of the S\&P 500 's revenues, assets, and employees. After 
$2003,80 \%$ of the companies in our sample reported that they gave $80 \%$ of their important legal work to twenty-five or fewer law firms, with almost $40 \%$ of companies distributing this share of the company's important matters to ten firms or fewer. ${ }^{77}$ Although this trend remains unevenly distributed across firms, and there may even be some evidence that the overall trend toward convergence is slowing, ${ }^{78}$ many of the largest companies (and therefore the most prized clients for firms) continue to move in this direction. Thus in 2005, the pharmaceutical giant Pfizer invited 120 law firms to compete for one of twenty coveted spots on the company's new preferred providers list. ${ }^{79}$ Less than four years later, Pfizer further slashed the number of law firms on the list to four. ${ }^{80}$

Moreover, the reasons companies give for moving toward this model also parallel the DuPont experience. Not surprisingly, cost is a significant factor. By concentrating their legal work in a smaller number of firms, companies hope to leverage their status as a "trophy client" to exact deeper discounts and package rates. Moreover, as another general counsel in our sample emphasized, for many companies "predictability is more important than the magnitude of the fee." 81 General counsel, like every other corporate manager, have to ensure that their department's spending stays within budgetary limits. By facilitating "bundling" of cases and fixed fees, many GCs believe that convergence makes it easier to achieve this goal. ${ }^{82}$

The trend toward convergence, however, extends beyond the kind of commodity work where price is likely to be the sole-or even the predominate-criterion for selecting counsel. ${ }^{83}$ Instead, companies that

comparing both interview and survey respondents and nonrespondents on a variety of metrics, we determined that in most respects the two subsamples were similar, although respondents tended to be larger and have higher demand for legal services than did nonrespondents. For a complete description of the study and a summary of its major findings, see Michele DeStefano Beardslee, John C. Coates, IV, Ashish Nanda \& David B. Wilkins, Hiring Teams from Rivals: Theory and Evidence on the Evolving Relationship in the Corporate Legal Market (June 22, 2009) (unpublished manuscript, on file with author).

77. Id. at 21-22.

78. Although $40 \%$ of the firms in our sample decreased the number of law firms accounting for $80 \%$ of the companies' total legal spending between 2003 and 2006, just under $30 \%$ increased the number of firms in this category. The remaining $30 \%$ of respondents remained essentially unchanged. See id. I return to the reasons why many companies may resist further converging their outside counsel relationships below.

79. Eriq Gardner, Pfizer Litigators Endure Beast of a Beauty Contest, CoRP. Couns., Oct. 31, 2005, http://www.law.com/jsp/law/sfb/lawArticleSFB.jsp?id=900005440167.

80. Gina Passarella, What's To Become of Wyeth Counsel After Pfizer Deal, LEGAL INTELLIGENCER, Jan. 28, 2009, at 1 (reporting Pfizer consolidation).

81. Confidential Interview with General Counsel (Apr. 1, 2008). Of course, companies care about the overall size of the fee as well. As another GC dryly noted, he had no interest in "buying every new partner at the firm a Jaguar." Confidential Interview with No. 7, General Counsel, Investment Bank (Nov. 2, 2006).

82. Passarella, supra note 80 (describing how Pfizer has begun giving all of its work in a given area to a single firm in return for a fixed fee).

83. Indeed, in our survey we specifically asked general counsel to discuss how they assigned "important" legal work where price was not the overarching determination. Nevertheless, convergence remained an important theme. 
have slashed the number of firms who do the bulk of their outside work are giving these preferred providers access to "premium" work as well. Indeed, GCs recognize that this is one of the major incentives for high quality firms to enter into these kinds of relationships. As a result, in return for discounted fees and some low-margin work, companies promise firms that they will also have preferential access to the company's more lucrative business. ${ }^{84}$

With respect to this higher-value work, cost is no longer the dominant factor. Instead, general counsels are looking for firms that will provide high quality service. But companies mean something different by "quality service" than most commentators-and most outside lawyers-typically think. A recent survey by BTI Consulting Group drives the point home..$^{85}$ When asked what they value most in an outside firm, the overwhelming plurality of general counsel responded "client focus." Not surprisingly, BTI found that this is what virtually every law firm believes that they are providing. ${ }^{86}$ But when the consultants asked clients and law firms what they meant by "client focus," they received very different answers. Twenty-one percent of GCs, again the overwhelming plurality, responded that "client focus" means "understanding our business." 87 Only 10\% of law firm respondents suggested a similar understanding. Instead, $21 \%$ of law firm respondents defined "client focus" as "doing what's best for the client." Only $3 \%$ of GCs offered this interpretation. ${ }^{88}$ Although it may not quite be fair to say that clients are from Mars and lawyers from Venus, our interviews confirm that GCs put a high premium on finding lawyers who "understand their business." 89 An increasing number are attempting to ensure that their lawyers meet this goal through convergence.

Given all of these factors, it is not surprising that convergence has become the buzzword for GCs in the United States, and increasingly abroad as well. ${ }^{90}$ Indeed, as the DuPont example suggests, the trend toward

84. As we will see, in most cases "preferential access" does not mean a guarantee, particularly for "bet the company" cases or transactions as to which the company reserves the right to seek out the "best" firm.

85. Conley, supra note 68 (discussing survey).

86. Id.; see also Robert Eli Rosen, "We're All Consultants Now": How Change in Client Organizational Strategies Influences Change in the Organization of Corporate Legal Services, 44 ARIZ. L. REV. 637, 671-72 (2002) (quoting a variety of law firm websites with slogans that promise to put "Clients First").

87. Conley, supra note 68 . Although this is obviously still only a minority of respondents, as BTI suggests many of the other answers commonly provided by GCs - e.g., responsiveness, following directions, even developing an early strategy for resolving disputes-can fairly be viewed as connected to the client's overall desire to have lawyers who understand how legal issues and disputes fit into the client's overall business strategy.

88. Id.

89. As one typical respondent put it, "they must understand our business and be able to work well with our business people. I generally select people that the business people trust. We might try different firms on different projects and the one that becomes the most trusted advisor is the one that I will use on an ongoing basis." Confidential Interview with No. 2 , General Counsel, Investment Bank (Oct. 4, 2008).

90. See Rosen, supra note 86 , at $665-66$. 
convergence has been even more pronounced in Europe. In perhaps the most dramatic case, Tyco International recently reduced the number of outside firms it uses in the U.K., Europe, and the Middle East from 250 to 1-the U.K.-based firm Eversheds. ${ }^{91}$ I will return to Tyco's experience below. But although Tyco may be the most extreme example, other European companies are following suit. The Linde Group, for example, recently chose DLA Piper to handle all of its European work, with the rest going to four other firms. Similarly, Honeywell has selected the UK firm Lovells in much the same manner, while Brady Corporation chose Eversheds. ${ }^{92}$ Even GE is moving to reduce substantially the 200 firms it currently uses in Europe. ${ }^{93}$

A quick look at the law firms that have been selected to play the lead role in these new arrangements underscores a second trend that has helped to reshape the relationship between companies and outside firms during the last decade. Eversheds, DLA Piper, and Lovells are all international firms that have expanded rapidly since the 1990s and can credibly claim to have something approaching a global footprint (so long as one excludes the United States from the map). Although the U.K. firms have been the leaders in international expansion, and indeed now rank among the largest firms in the world-both Eversheds and DLA each have over 2000 lawyers world-wide, with Magic Circle firms like Linklaters, Freshfields, and Clifford Chance topping the scales at close to 4000 -their U.S. cousins have not been far behind, and of course are far ahead with respect to their coverage in the United States. Collectively this wave of consolidation among the world's top law firms has in turn facilitated a new rapprochement between companies and firms.

\section{Consolidation}

By any measure "[d]uring the last three decades, large law firms have mushroomed in size and geographic dispersion."94 In the 1960s, there were only twenty law firms in New York City with more than fifty lawyers, with the largest, Shearman \& Sterling, consisting of 125 lawyers..$^{95}$ By the turn of the twentieth century, there were more than 250 U.S. firms larger than Shearman's old size, with more than ten firms of over 1000 lawyers. The growth since 2000 has been even more torrid - until, of course, the fourth quarter of 2008. In 2006, the median size of the nation's 250 largest firms had ballooned to over 500, with more than twenty firms topping the scales

91. See Richard Lloyd, Firm Commitment: How Tyco and Other Major Corporations Are Redefining the Client-Law Firm Relationship in Europe, FocUS EUR., Summer 2008, at $28,28-32$.

92. Id. at 32 .

93. Id.

94. Marc Galanter \& William Henderson, The Elastic Tournament: A Second Transformation of the Big Law Firm, 60 STAN. L. REV. 1867, 1882 (2008).

95. SMIGEL, supra note 27 , at 34 n.9. 
at over 1000-and four breaking the 2000-lawyer barrier. 96 By some estimates, almost 10,000 lawyers-nearly one quarter of all law school graduates-were expected to begin their careers in a large law firm in 2006.

Along with getting bigger, firms have also been expanding in geographic scope. Since 2000 , for example, the 250 largest U.S.-based law firms have more than doubled the number of lawyers in Europe and increased their headcount in Asia by more than sixty percent. ${ }^{97}$ U.K.-based firms have been growing at an even faster pace. ${ }^{98}$ Moreover, much of this growth has been accomplished through merger and acquisition. Until recently, law firm mergers were virtually unheard of. Between 2000 and 2008, merger activity among law firms increased in virtually every succeeding year, including megacombinations such as Washington D.C.'s Wilmer Cutler with Boston's Hale and Dorr to form WilmerHale and New York's Dewey Ballentine and its longtime rival LeBouef Lamb Green \& Macrae to form Dewey LeBouef. 99

The result is that large global companies increasingly interact with law firms that are themselves large and globalized. Nor is this a coincidence. When asked to explain why their firms have grown so rapidly in recent years, firm leaders most often answer that they are simply responding to the demands of their clients. ${ }^{100}$ Needless to say, the lack of agency implied by this characterization overlooks the firms' own interest in pursuing a growth strategy. There is plenty of evidence that firms are growing to increase their profits by acquiring new clients, and indeed whole new areas of practice. Nevertheless, even firms that are ruthlessly focused on increasing profits have come to see the importance of strengthening their relationships with their most important clients. 101 As a result, "premium work for premium clients" has become as much of a buzzphrase for law firms as finding lawyers who "understand our business" has become for clients.

The U.K. firm Linklaters is a case in point. ${ }^{102}$ As my colleague Ashish Nanda documents, after a period of unprecedented growth between 2001 and 2004, in which the firm opened several new offices and completed five international mergers, Linklaters found that it was falling behind its U.S. counterparts in profitability. The firm's chairman Tony Angel responded

96. The NLJ 250, NAT'L L.J., Nov. 13, 2006, at S3.

97. Lindsay Fortado, Steady Global Gains, NAT'L L.J., Jan. 23, 2006, at 1.

98. See The Global 100, AM. LAW., Oct. 2007, at S1.

99. See June D. Bell \& Aric Press, Law Firm Leaders Have Mergers on the Mind, LAW FIRM INC., Feb. 12, 2007, http:/www.law.com/jsp/article.jsp?id=1170928976695 (discussing the "merger momentum" in large law firms).

100. See Galanter \& Henderson, supra note 94, at 1882 (citing increased demand as the reason why law firms have grown so dramatically over the last three decades).

101. See, e.g., David Temporal, Beyond Client Care, AM. LAw., July 2001, at 65 (noting that "[a]t many firms, it is typical to see the top 50 clients generate between 45 and 60 percent of the firm's income").

102. The following description is taken primarily from Ashish Nanda \& Lauren Prusiner, Linklaters (A): Seeking Clear Blue Water 1 (Harvard Law Sch. Ctr. on Lawyers \& the Prof'1 Servs. Indus., Case Study No. 08-01, 2007). Some of the information discussed is from the (B) and (C) cases that are not yet publicly available. 
by instituting a dramatic plan to increase the firm's profitability and to place "clear blue water" between it and its competitors. At the core of this plan was a mandate to concentrate the firm's resources on serving its largest and most important clients. In an internal study, the firm's management had determined these clients accounted for a disproportionately large share of the firm's profits and that when all costs were fully factored in, the firm actually lost money on many of its smaller client relationships. ${ }^{103}$

The firm therefore instituted a rigorous-and in the eyes of many, draconian-policy to "prune" its client list. Lawyers, and indeed whole offices, serving smaller, more local clients were expressly told to drop these matters and to refocus their efforts on providing support for the firm's large global clients. Lawyers, and indeed whole offices, which were unable to do so were politely, but firmly, asked to leave the firm. ${ }^{104}$ The result was a dramatic increase in the firm's profitability. Although Linklaters's policy is undoubtedly more drastic than most, in the last two years its strategy has been copied to a greater or lesser extent by virtually all of the top U.K. firms and by many U.S. counterparts as well. Nor is this trend confined to firms like Linklaters that have global ambitions and seek only to compete for work at the top of the corporate food chain. As companies shrink the number of outside firms that they use and package even the legal work that they put out for competitive bid in ever-larger bundles, there are fewer opportunities for firms to win new clients. ${ }^{105}$ At the same time, the pressure by even long-standing clients to cut fees has led many firms to try to increase revenues by expanding the volume of work that they do for each client. Finally, the expanded size and geographic scope of most law firms has generated a relentless pressure in these institutions for partners to crosssell the firm's services. The net result of all of these trends has been a growing awareness among firms that the best way to ensure their profitability is to leverage their relationships with their existing clients. This, in turn, has put pressure on firms to find ways to improve the level of service that they give to these increasingly important clients.

\section{Integration}

As companies and firms have moved closer together, the boundaries that have traditionally separated lawyer and client have grown increasingly permeable. Not surprisingly, companies like DuPont have been at the forefront of this trend. In return for getting on the company's list of "preferred providers," the law firms that work for DuPont are required to

103. Michael D. Goldhaber, Touched by an Angel, AM. LAw., Oct. 2007, at 116, 118 (reporting that the firm's forty biggest clients and another forty preferred global clients account for fifty-two percent of the firm's billing).

104. Id. at 118-19 (reporting that "partners who do not serve the lucrative cross-border needs of priority clients are superfluous" and documenting that "125 partners left or retired in the last four years").

105. This also helps to explain why firms have increasingly sought to acquire new clients by buying lawyers (and sometimes firms) with large books of business. 
adopt common practices and systems that allow the company to both easily gain access to its files and billing information and to create virtual teams of lawyers across the network to work on the company's matters. To reinforce these common practices, the company meets regularly with various partners from the firms on its list to educate them about DuPont's issues and goals and to reinforce the need to work collaboratively to solve the company's problems. ${ }^{106}$

Many law firms have been taking similar actions to restructure their practices to ensure better service to their best clients. Thus, in addition to being organized by practice specialty and geography, many firms have adopted dedicated "client teams" to service their most important client relationships. ${ }^{107}$ In addition to providing interdisciplinary support, these teams often take various measures to integrate themselves into the client's business, such as bringing in businesspeople from the client to teach the lawyers about the company's practices and competitive position, and sending lawyers to train their in-house counterparts and business leaders about legal issues of particular relevance to the company. ${ }^{108}$

Indeed, many firms are going beyond seminars and periodic training to place associates (and sometimes even partners) to work full-time in the legal departments of their best clients for limited periods of time. These "secondments" have been popular in the U.K. for some time. ${ }^{109}$ Since 2000 , however, the practice has gained considerable traction in the United States as well. ${ }^{110}$ Reverse transfers that allow in-house lawyers to spend six months or a year working in the office of the company's most important law firm have also begun to sprout up. And some clients and firms have taken to jointly interviewing law students that the firm intends to hire as a way of both getting the client's buy-in and as a means of signaling to new recruits the importance of getting to know the client's personnel and

106. Dull \& Gould, supra note 70.

107. See Rosen, supra note 86 , at 672 (noting that consultants now advise law firms to organize themselves "around industries rather than practice areas"); Peter D. Zeughauser, Optimal Organization, AM. LAW., Mar. 2001, at 63 (noting the growth in "client relationship partners" in "forward looking" law firms).

108. See Rosen, supra note 86 , at 676 (noting that "[l]aw firms also sell added value through improved corporate processes by selling training"); see also Ross DAwson, Developing KnOwledge-Based Client Relationships: The Future of Professional SERVICES 53 (2000) ("It is increasingly common for corporate counsel to specifically request knowledge transfer from their legal firms.").

109. The practice began in the U.K. as a way for U.K. and European companies with relatively small general counsel offices to expand their internal legal capabilities without having to invest the resources in hiring lawyers full time. As the process became institutionalized, however, both companies and firms recognized that it was also a good way to build institutional knowledge and trust.

110. See Gina Passarella, Loaning Out Lawyers To Get a Bigger Piece of the Corporate Pie, Legal InTElligencer, Oct. 26, 2006, http://www.law.com/jsp/cc/PubArticleCC.jsp? id=11617671191737 (describing the use of secondment programs by U.S. law firms to deepen their relationship with their best clients in an effort to increase business). 
business. ${ }^{111}$ Nor is such collaboration confined to the associate level. In one of our interviews, for example, the general counsel of a large brokerage company bragged that he had arranged for a partner who had done important work for the company, but whose firm did not, to move to another firm with which the company did substantial business. ${ }^{112}$ Although our interviews suggest that this kind of aggressive matchmaking is relatively rare, it nevertheless underscores the degree to which the boundaries that have traditionally separated companies and firms are becoming increasingly porous. As Robert Rosen explains,

Outside counsel are quick to embrace outsourcing and porous borders because these organizational strategies can lead to more relational work, rather than one-shot transactions. . . . This allows for a "rich two-way knowledge transfer and relationship development [as the proponents of outsourcing argue] ... and [the client] becomes far more inclined to choose that law firm over others it knows less well."113

As Rosen goes on to explain, this trend has been facilitated by a set of connected trends in corporate America that encourage companies to invite outside "consultants" inside the organization to be a part of corporate decision making.

\section{The Boundaryless Organization}

Rosen argues that companies have implemented four interconnected practices that have fundamentally changed the way that these entities contract for, and utilize the services of, outside professionals such as lawyers: downsizing, outsourcing, self-managing teams, and porous borders. ${ }^{114}$ Throughout the 1990s, companies shed workers in an effort to "reduce[] bloated bureaucracies" by eliminating middle managers and headquarters staff. 115 In place of these top-down controls, companies have created "self-managing project teams" that are given wide discretion both to define their own goals and assemble expertise from both inside and outside the company to achieve their objectives. ${ }^{116}$ The result, Rosen argues, is that companies have "shift[ed] away from a 'transmission belt' delegation of powers from principal to agent towards one that emphasizes 'network coordination" among various constituencies, subject to an overall assessment of risks and rewards. ${ }^{117}$

At the same time, many companies have also turned to outsourcing what were once considered core organizational functions. In addition to reducing

111. Sheri Qualters, Citigroup Lawyers Toil at Law Firms, NAT'L L.J., Oct. 9, 2006, at 8 (describing a joint hiring program between Citigroup and three of its primary law firms)

112. Confidential Interview, General Counsel, Brokerage Company.

113. Rosen, supra note 86 , at 670 (quoting DAwsON, supra note 108 , at 162).

114. Id. at 641 . Rosen also argues that these changes have transformed in-house counsel offices as well. I return to these observations below.

115. Id.

116. Id. at $643-47$.

117. Id. at 643 . 
costs, Rosen argues that companies see outsourcing as a way to tap into expertise and experience held by outsiders who interact with multiple corporations. As a result, "the strong boundaries that once separated firms have become less distinct, while ... market transactions have become more intimate." 118

Rosen argues that these connected changes have fundamentally transformed the relationship between inside and outside counsel. In the heyday of the Inside Counsel Movement, powerful general counsel like Ben Heineman aggressively managed the interactions between outside firms and the company with the goal of reducing both the cost and scope of their work. ${ }^{119}$ In companies that have been redesigned by downsizing, selfmanaging teams, outsourcing, and porous boundaries, outside firms are increasingly being invited to become part of the multidisciplinary project team that carries out the company's core functions. As Rosen concludes, in the modern corporation, "relations between inside and outside counsel . . . may be summarized in one word: "partnering." 120

Recent trends in the career trajectories of in-house counsel are likely to accentuate these broader trends.

\section{Inside Counsel Movement}

When we prepared to send out our survey to general counsel in the S\&P 500 , we stumbled upon a surprising fact: a significant number of the chief legal officers listed in the most recent databases we could find were no longer at their companies. In a separate paper, John Coates has probed further and discovered that contrary to the picture conveyed by well-known figures like Ben Heinemann, who spent almost twenty years with General Electric, turnover rates among general counsel are surprisingly high. Indeed, in recent years turnover among general counsels has exceeded the rate at which CEOs have departed their companies by almost $50 \%$. $^{121}$ Thus in 2005, nearly twice as many GCs turned over as CEOs (29\% to $15 \%) .{ }^{122}$ Although there are many reasons for these departures, a primary cause is the development of a burgeoning lateral market for GCs who want to move to similar positions in larger (and presumably better paying) companies.

High turnover rates among GCs are likely to increase the degree to which companies rely on their primary outside law firms. One of the principal arguments supporting the Inside Counsel Movement was that in-house

118. Id. at 649 (quoting Paul DiMaggio, Introduction: Making Sense of the Contemporary Firm and Prefiguring Its Future, in THE TWENTY-FIRST-CENTURY FIRM: Changing EConomic Organization In InTERnational Perspective 3, 4 (Paul DiMaggio ed., 2001)); see also JOSEPH L. BADARACCO, JR., The KNOWLEDGE LINK: How FIRMS Compete Through Strategic Alliances 107-28 (1991). I return to Badaracco's analysis below.

119. Rosen, supra note 50, at 484-90.

120. Rosen, supra note 86 , at 670 .

121. John C. Coates, IV, CLO Turnover (unpublished research, on file with author).

122. Id. 
lawyers would be a better source of institutional memory about the company's history and practices than outside firms. As lateral movement among associates and even partners escalated throughout the 1990s, this argument gained additional currency. As a result, companies no longer felt that they needed to have stable relationships with their outside counsel and instead could move work inside to preserve institutional memory. But as the careers of inside lawyers have become similarly volatile, the pendulum may be swinging back in the other direction. When a company hires a new general counsel - even one with previous experience in a similar position at another company - that person will inevitably have a steep learning curve to get up to speed on the company's legal history and preferred method for doing business. To fill in these gaps, the new GC is likely to look to the accumulated experience and knowledge of the company's primary outside lawyers. Similarly, general counsels who are contemplating making a move may fear tampering with their existing primary outside counsel relationships for fear that the speculative gains in cost and quality of bringing in a new firm either will not materialize, or will prove not to be worth the time and energy that the GC would have to expend to disrupt the status quo.

The fact that many general counsels' offices have downsized themselves in recent years reinforces this tendency. To be sure, in-house counsel has been the fastest growing segment of the legal profession for several years, ${ }^{123}$ but this overall growth masks the significant number of cuts that have occurred in many companies. Rosen reports, for example, that all of the legal departments he interviewed in the mid-1980s had experienced at least one round of downsizing by the mid-1990s. ${ }^{124}$ Similarly, there are many anecdotal reports of companies slashing their in-house staffs after a merger or other consolidation in an effort to reduce costs. ${ }^{125}$ To be sure, there are companies like GE that continue to believe strongly in maintaining (and indeed expanding) their in-house legal staff. But for every GE, there are many others who have reduced the number of inside lawyers or, at a minimum, dramatically slowed the rate of growth. As a result, there is a wide variation in the size of general counsel offices among even the largest companies-with close to thirty percent maintaining relatively modest departments with fewer than twenty-five lawyers. ${ }^{126}$ Teams of this size are likely to manage their relationships with outside counsel significantly

123. See HEINZ ET AL., supra note 58.

124. See Rosen, supra note 86 , at 642 .

125. See Conley, supra note 68 (reporting that some "companies are spending more than ever on outside counsel following budget cuts that have forced GCs to slash their in-house staffs by 40 percent over the past five years").

126. See In-House Tech Survey, CORP. Couns., Mar. 2007, at 78, 78-81. Although accurate numbers are difficult to come by, this survey of Fortune 500 companies found that almost $30 \%$ had fewer than 25 in-house lawyers while only about one quarter had departments over 100 -and fewer than $5 \%$ with megadepartments of 500 or more. As this indicates, in this regard as in so many others, GE is an outlier. 
differently than Ben Heinemann managed GE's external legal service providers from the company's 1000 -plus lawyer in-house platform. ${ }^{127}$

\section{A New Legal Keiretsu?}

Collectively, these five interlocking trends-convergence of work in the hands of a limited number of "preferred" firms, consolidation of the firms themselves through merger and acquisition, greater integration and knowledge transfer between companies and firms, changes in the organizational structure of companies that promote integration and blur the boundaries between the inside and the outside, and increasing instability and contraction in general counsel offices - are spurring the creation of a new working partnership between companies and their primary outside firms. Although general counsels continue to insist that they "hire lawyers not firms," in reality their relationship with their primary firms is a good deal stickier than this standard slogan would suggest.

To be sure, this is not the old fashioned marriage that firms and clients entered into during the Golden Age. Firms that manage to make it on a company's preferred provider list can lose their privileged status for reasons of incompetence or disloyalty. Even if they perform well, most companies still put the arrangement up for periodic review and renegotiation. And firms still compete with others on the list for particular assignments, or to grow their share of the relationship.

More fundamentally, outside firms and in-house lawyers still actively compete with each other for both work and influence. Companies compete by taking their work in house or by switching (or threatening to switch) their business to other law firms. Firms compete by selling the knowledge they gain through their representation of a given company to other clients and by "firing" existing clients in favor of new ones who can provide more lucrative work.

Finally, firms and clients are engaged in a fierce war for talent. For years, companies have routinely cherry picked the best associates and partners working in their primary firms to join their in-house staff. In recent years, it has become increasingly common for law firms to return the favor by poaching senior in-house lawyers to return to private practice. Although these personnel exchanges are often mutually beneficial in that they strengthen the ties between the company and the firm (another example of why these ties are increasingly strong) they also can pose competitive challenges for each party. A company that hires a partner who was previously handling its trademark work may no longer need to send this work outside. Similarly, a company that loses a senior in-house lawyer to one of its law firms risks seeing potentially valuable knowledge about the 76.

127. For a discussion of some of the potential differences, see Beardslee et al., supra note 
company's internal practices and procedures sold to competitors. ${ }^{128}$ The consternation that many firms feel when general counsel berate them for their lack of diversity while at the same time hiring away their most promising minority lawyers underscores that even the most cooperative exchanges between parties and firms nevertheless contain an element of competition.

Indeed, it is precisely this paradoxical element of simultaneous cooperation and competition-"cooptition," to use a phrase employed by management scholars-that defines the modern relationship between companies and firms. ${ }^{129}$ As a result, these relationships increasingly have come to resemble the kind of strategic alliances or partnerships that many companies have entered into with other long-term suppliers in order to achieve common objectives. ${ }^{130}$ Like the partners in these arrangements, both corporations and law firms depend on each other to provide crucial information and expertise if the purposes of their cooperative venture-i.e., winning the case, successfully completing the deal, etc.-are to be achieved. Corporations depend upon their lawyers to supply specialized legal knowledge; to gather information; to interface with competitors, consumers, and government officials; and to monitor and mediate conflicts within the organization. For their part, firms depend upon their corporate clients to supply accurate information about corporate goals and practices; to follow the firm's instructions on matters of legal compliance; and, of course, to provide the firm with the capital that it needs for its survival, including reputational capital in the form of referral to other potential clients. In return for receiving these goods, each partner demands a certain level of control over the other partners' internal affairs. As Richard Painter argues, in their roles as "monitors" and "dealmakers," outside counsel exercise substantial control over the corporation's internal affairs. ${ }^{131}$ For the reasons set out above, corporate clients now exercise similar control over the internal affairs of outside firms.

The relationship between Chrysler Corporation and its principal suppliers in the mid-1990s provides an instructive analogy-and as I will argue

128. Conflict of interest rules partially protect against this problem. See MODEL RULES OF PROF'L CONDUCT R. 1.7 (1983). However, much of what a company may be afraid of losing may not be covered by such rules. See generally John S. Dzienkowski, Positional Conflicts of Interest, 71 TEX. L. REV. 457 (1993).

129. See generally Claudia Loebbecke, The Future of Innovation ... the Benefits of Being Realistic, in THE FUTURE OF INNOVATION (Bettina Von Stamm \& Anna Triflova eds., 2009) (discussing cooptition).

130. See Gilson et al., supra note 13, at 447 (observing that "an interesting set of firms engages in a process of iterative co-design, in which suppliers contribute to the redefinition of interface specifications for new products by building on their experience in manufacturing existing models" and that these methods are today a familiar part of the new economy). See generally BADARACCO, supra note 118.

131. See Richard W. Painter, The Moral Interdependence of Corporate Lawyers and Their Clients, 67 S. CAL. L. REv. 507, 520-53 (1994). 
below, a cautionary one. ${ }^{132}$ After years of losing market share to Japanese firms, Chrysler undertook a detailed benchmarking study of Honda, considered then-and now-to be one of the best-run companies in the world. As a result of this review, the U.S. car company decided to try to institute some of its Japanese competitor's practices. At the core of this effort was a radical transformation of Chrysler's relationship with the parts manufacturers who constituted the firm's primary suppliers.

Chrysler, like all of its U.S. competitors, was organized functionally by specialty and developed its products in a traditional sequential process in which Chrysler engineers designed components for its cars and then sent them out for competitive bids from all of its potential suppliers. Contracts were awarded to the lowest bidder with little attention to prior history or performance. As a result, "the typical relationship between Chrysler and its suppliers was characterized by mutual distrust and suspicion" as each party tried to extract the maximum gain from what both sides viewed as a zerosum game. ${ }^{133}$

Honda's organization and relationships with its primary suppliers were very different. At the Japanese company, workers were organized around multidisciplinary product development teams that were given "cradle-tograve" responsibility for all aspects of the development of a vehicle. Suppliers, who were chosen primarily on the basis of their past performance and relations with the company as opposed to price, were invited to participate in these product development teams at an early stage and, in return for continued high performance, were promised long-term contracts, typically lasting for the life of the vehicle. As a result, relations between Honda and its suppliers were characterized by a high degree of trust and collaboration.

Beginning in 1989, Chrysler began a campaign to adopt these practices. The company changed its internal organization from functional divisions to cross-functional teams. At the same time, it cut the number of suppliers it would work with in half and began to involve them early in the design process by exchanging engineers and "presourcing" responsibility for particular components. Suppliers were given long-term contracts for the life of the vehicle and beyond. And while the company requested discounts in return, prices were set specifically to ensure that suppliers would be able to achieve reasonable and sustainable profits. As the company's president made clear, " All I want is your brainpower, not your margins."”134

Most radically of all, Chrysler rolled out a Supplier Cost Reduction Effort (SCORE) under which suppliers were encouraged to provide

132. The following account is taken from Jeffrey H. Dyer, How Chrysler Created an American Keiretsu, HARV. BuS. REV., July-Aug. 1996, at 42, 42-56. For a description of the Japanese models that Chrysler attempted to copy, see Mari Sako, Supplier Development at Honda, Nissan, and Toyota: Comparative Case Studies of Organizational Capability Enhancement, 13 INDUS. \& CÖP. CHANGE 281 (2004).

133. Dyer, supra note 132, at 43.

134. Id. at 53 (quoting Chrysler president Robert Lutz). 
suggestions about how Chrysler could improve its processes. In order to induce suppliers to participate, Chrysler agreed to share half of any resulting cost savings with the company that made the suggestion. In 1992, Chrysler made SCORE a formal part of its supplier rating system, along with more traditional measures such as price, quality, and delivery. By the mid-1990s, SCORE accounted for fifteen percent of a supplier's performance and often made the crucial difference in whether a supplier would be able to expand its business with the company. Indeed, the program became so successful that the company expanded it to provide incentives for suppliers to develop ideas that would reduce vehicle weight, warranty claims, and complexity. The program has proven to be enormously successful, rising from 875 suggestions worth a total of $\$ 170.8$ million in its first year of operation to 5300 suggestions generating $\$ 1.7$ billion in savings when the program was assessed in 1995.

More generally, by moving from a "logic of power," in which the company attempted to reap maximum advantage from its leverage over its suppliers, to a "logic of embeddedness," in which the company worked to build a mutually cooperative relationship in which both parties would gain, Chrysler was able to dramatically reduce its overall costs while improving both the speed of its production process and the overall quality of its cars. ${ }^{135}$ Throughout the 1990 s, the company continued to find ways to give "voice" to its suppliers, including establishing an advisory board of executives from its fourteen biggest suppliers and holding an annual meeting with its top $150 .{ }^{136}$ For their part, suppliers demonstrated their commitment to the relationship by creating a common technology platform with the automaker and establishing dedicated equipment, systems, processes, and staff exclusively to serve Chrysler's needs. Although the automakers' current woes are well documented, as recently as 2007, Chrysler's collaborative relationships with its suppliers were continuing to produce impressive dividends. ${ }^{137}$

From the preceding sections, it should be clear that the evolving relationship between many companies and their principal outside law firms

135. Id. at 43 (noting that "[ $\mathrm{t}] \mathrm{he}$ cost of developing a new vehicle has plunged an estimated $20 \%$ to $40 \%$ " at the same time that the company "has managed to produce one consumer hit after another" and "profit per vehicle has jumped from an average of $\$ 250$ in the 1980 s to ...\$2,110 in 1994"). On the difference between the logics of power and embeddedness, and how the former can paradoxically diminish the putatively stronger party's ability to extract value from an exchange relationship, see Gulati \& Sytch, supra note 14, at 59-60. As a Chrysler manager interviewed by the researchers summarized the difference between the company's orientation before and after the new initiative, "The thinking used to be here that we'd like to see a supplier totally dependent on us and then we'd have the thumb over them. Now we recognize that neither extreme is good." Id. at 60 (internal quotation marks omitted).

136. See Dyer, supra note 132, at 55; Helper \& Sako, supra note 15, at 79-80 (cataloging measures taken by U.S. auto companies to give voice to their suppliers).

137. See Gulati \& Sytch, supra note 14. As the authors demonstrate, Ford also pursued a similar strategy with its major suppliers with similar effects. See also Helper \& Sako, supra note 15, at 80-82 (demonstrating the correlation between voice relationships and improved performance). 
has come to take on many of the characteristics of the American Keiretsu that Chrysler forged with its suppliers in the 1990s. Although there are clearly differences between the two situations, the recent engagement between Tyco International and the U.K. law firm Eversheds underscores that the differences are not nearly as great as one might suspect.

\section{The SMARTER Model ${ }^{138}$}

When Trevor Faure took over the legal department of Tyco International's operations for Europe, the Middle East, and Asia in 2004, the department was in a state of total disarray. Fresh from the major accounting scandal that nearly destroyed the parent company, Faure was given explicit instructions to improve the competence and integrity of the legal function. To achieve this objective, Faure instituted a systematic examination of how the company was spending its legal resources, both internally and with outside firms. What he quickly discovered was that notwithstanding significant increases in spending on both internal and external resources, the legal department was doing a poor job of managing its known legal expenses - and an even worse job of providing the kind of comprehensive legal coverage that could prevent legal problems from occurring in the first place.

Armed with this knowledge, Faure developed a plan to reallocate the company's legal spending in a manner that better protected its interests. At the core of Faure's strategy was a proposal to achieve the ultimate in convergence by slashing the number of outside firms the company used from 250 to a single provider. After interviewing several candidates, Faure settled on the 2000-lawyer U.K. firm Eversheds. The two-year deal covered a wide range of work, including labor and employment, IP, compliance, and litigation. All told, Eversheds was expected to gross $\$ 20$ million per year in fees.

Implementing this plan, however, proved more difficult than either Tyco or Eversheds anticipated. Indeed, after the first year, Faure almost pulled the plug on the arrangement because Eversheds had not yet learned how to control the company's legal costs. For its part, the law firm claimed that the sheer volume of work-1000 live matters followed by 100 new matters a month, spread over thirty jurisdictions-was simply too much for even such a large global firm to absorb. In the end, however, because of the significant investment that both parties had already made in the new relationship, the company and the law firm chose voice rather than exit and agreed to a new deal that brings the sides even closer together.

Specifically, the new deal makes it even clearer than before that the company and firm will share both the risks and the rewards of Tyco's legal

138. The account below is taken primarily from a series of discussions with Tyco's Trevor Faure in connection with a forthcoming case study I am writing on the Tyco/Eversheds relationship as well as Faure's recently published book on the SMARTER Model. Trevor Faure, The SMARTer Legal Model: More from Less (2010). 
fate. To accomplish this objective, the company and the firm have agreed to a set of benchmarks for specific kinds of cases. For basic "commodity work," the company agrees to pay Eversheds for 10,000 hours of work at reduced rates. If the firm exceeds this preset number of hours, it will receive nothing for the first 1250 hours, and a dramatically reduced rate for any hour thereafter. If, on the other hand, the firm is able to complete the tasks in under the prescribed amount of time, the company will allow Eversheds to bill for fifty percent of the hours that it did not work up to the 10,000 hours agreed upon to achieve this objective. For all litigation under $\$ 1$ million, the firm will receive a twenty-five percent success premium on top of its discounted fees for any case it wins - and will suffer a ten percent penalty from its discounted rates if the case is lost. With respect to highervalue litigation and transactional work, the deal provides that Eversheds be paid its standard fees minus a smaller discount. Finally, premium work, such as "bet-the-company" litigation and structuring transactions, is expressly not included in the deal, but Eversheds will be given an opportunity to compete for these matters along with other firms.

The most innovative aspects of the new arrangement between Tyco and Eversheds, however, fall outside of these typical parameters. These terms provide that in addition to making money on the fees the company pays it for its work, Eversheds can also profit if the firm hits a number of additional targets designed by the company to further what it considers to be important objectives. For example, the deal specifies that the firm will pocket a bonus in excess of $\$ 100,000$ if the firm improves Tyco's "client satisfaction" as measured by a survey given to the company's senior managers every October. The firm will also take home a six-figure bonus if it meets certain targets for diversifying its legal and support staff. Finally, the arrangement contains an incentive for Eversheds to help Tyco avoid getting into legal trouble in the first place. The firm will take home another six-figure bonus if it is able to reduce the number of lawsuits filed against Tyco by fifteen percent over the number filed in the previous year. To give Eversheds the chance to meet this target, Tyco promises to give the firm access (at the law firm's expense) to Tyco's business processes and people.

By providing specific rewards for helping the company to achieve its own objectives, Faure hopes to create a "win-win" mentality between the company and Eversheds. As he told The American Lawyer, he hoped to avoid the "winner-take-all" mentality that typically characterizes the relationship between outside counsel and firms and to create a relationship "that encourages the right behaviors from both sides."139 As the editors of the magazine note, the result is a unique "two-way partnership [that] ties the firm to the client but ... [also] ties the client to the firm."140

As indicated above, the Tyco/Eversheds deal is indeed unique in both its scope and innovation. But it is also clear that other companies are looking

139. See Lloyd, supra note 91 , at 31 .

140. Id. 
closely at Tyco's experience. Since news of Faure's SMARTER model hit the press, a steady stream of general counsel have beaten a path to his door to see if they can adopt some or all of his methods. In 2008, Tyco's Trevor Faure was named "In-House Lawyer of the Year" by The Lawyer, which specifically praised the company's creation of "win-win" incentives such as paying the firm a bonus for reducing litigation against the company. ${ }^{141}$ Given the overall trend toward convergence, it is only a matter of time before aspects of Faure's model will be copied by other companies. ${ }^{142}$ Even companies that do not embrace all aspects of the SMARTER model are increasingly exploring mechanisms to encourage "risk sharing" by their primary law firms through mechanisms like "value billing" and the delivery of "products" that standardize templates and tools in ways that are guaranteed to produce results. ${ }^{143}$

Indeed, in the last few years an entire industry has sprouted up to help companies and firms enter into collaborative relationships in which both the benefits and the costs of managing the company's legal risk are shared between client and lawyer. Consider, for example, eLawForum. ${ }^{144}$ Begun as an online "meeting" site designed simply to put companies with work to give out together with firms qualified to carry out these assignments, eLawForum has evolved into a full-fledged matchmaking service that works with both companies and firms to bundle and price legal work in a manner that allows an equitable sharing of both risks and rewards by both clients and firms. eLawForum works with clients to do the kind of 360degree review of their legal problems and resources that Faure initiated at Tyco and then, crucially, to share this assessment with a group of law firms that the company has precleared as being qualified to do the work.

Armed with this knowledge, the law firms then engage in a competitive bidding process for the fixed fee at which the law firm will undertake the representation. After an initial set of bids is received, eLawForum then works with both the company and the finalists to find the firm that the company feels will do the best job for the best price. Although the company is under no obligation to accept the lowest bid - and often does not-the agreed-upon price is almost always significantly below what the company had historically paid for the services. ${ }^{145}$ Once the basic terms

141. The Lawyer Awards, LAWYER, June 25, 2008, http://www.thelawyer.com/thelawyer-awards-freshfields-scoopes-law-firm-of-year/133555.article.

142. Indeed, Faure will soon be spreading the gospel himself. In February 2009, Faure left Tyco to become the worldwide general counsel for Ernst \& Young. I return to the implications of this move below.

143. Rosen, supra note 86, at 677.

144. Most of what follows comes from Clayton Christensen's excellent case study on the company. See Clayton M. Christensen \& Scott D. Anthony, eLawForum: Transforming Legal Services, INNOSIGHT (Innosight, LLC, Watertown, Mass.), Jan. 31, 2003, at 1, available at $\mathrm{http}: / / \mathrm{www}$.innosight.com/documents/elawforum.pdf.

145. The relationship between Unocal and the D.C. litigation firm Howrey is a case in point. After an eight-round bidding process conducted by eLawForum, Unocal hired Howrey to handle all of its environmental litigation for five years for a fixed fee paid quarterly and a variety of incentives. See Heather Smith, The Fix Is In, AM. LAw., Nov. 
have been agreed to, eLawForum then works with the two parties to produce a "joint venture agreement" that clearly spells out how the work will be conducted-including the rights and obligations of each party to provide necessary information and cooperation, ${ }^{146}$ the parameters for success, and how the risks and rewards of the work will be divided.147 Similar services are already in the works. ${ }^{148}$

Just like the keiretsu between Chrysler and its suppliers, the goal of all of these arrangements is the same: to "encourage collaboration between client and law firm" in ways that both reduce costs and improve overall performance. ${ }^{149}$ As one enthusiast put it,

"Rather than have the client wait until the proverbial brown stuff has hit the fan, we get involved much earlier, often before a lawsuit is filedsometimes immediately when a complaint letter is sent, or even before, when an issue is identified. This is not only helpful for [the client]. It is to our benefit as a firm to avoid mass litigation under this contract." 150

It is also to the firm's benefit to keep the relationship in place. And, like it or not, companies will often conclude that the same is true for them as well.

\section{Turning the Titanic}

In the end, the growing interdependence between companies and firms makes it increasingly difficult for either side to walk away from these new relationships. To be sure, all of these new partnerships contain formal escape clauses. Companies invariably reserve the right to scrap the deal if they are unhappy with the firm's performance. ${ }^{151}$ And even if the firm

2005 , at 54 . Howrey was not the lowest bidder for the work. Instead, the firm, which had represented the oil company on insurance and commercial cases but not on environmental litigation, impressed the company's general counsel with its "business-minded" approach that allowed the firm to tell the company "how they and we would make money" on the deal. Id. at 57 (internal quotation marks omitted).

146. Clients typically promise to provide the firm with accurate and complete information about cases and outcomes in a timely fashion. For their part, firms promise not to "bait and switch" by ensuring that partners who say they will work on the client's matters actually do so. See id. at 58; Christensen \& Anthony, supra note 144.

147. For example, in the Unocal/Howrey deal, the two parties will split any savings that Howrey generates by bringing in matters under the company's cost targets and will receive a performance bonus for every twenty cases that it resolves under the firm's historic cost of $\$ 500,000$ per case. See Smith, supra note 145 , at 57 . A similar deal negotiated through eLawForum between Tyco International and Shook, Hardy \& Bacon includes six different opportunities for the firm to be paid a bonus for achieving certain results. Id. at 58 .

148. For example, Legal OnRamp is an invitation-only social networking site that connects in-house legal departments to outside lawyers. See Anna Oberthur, Virtual Connections: Lawyer-Only Sites Help Boost Online Networking, CAL. LAW., Mar. 2008, http://www.callawyer.com/story.cfm?pubdt=NaN\&eid=892326\&evid=1.

149. See Smith, supra note 145 , at 58 .

150. Id. at 60 (quoting the relationship partner for Morgan Lewis about its fixed-fee contract with Cisco Systems to handle all the company's litigation for two years).

151. See id. at 58 (noting that all of the contracts arranged by eLawForum she reviewed "include provisions allowing the clients to end the arrangements if they're unhappy with the work"). 
performs admirably, the arrangements are always subject to periodic renegotiation and revision as was done by Tyco and Eversheds. Finally, in all but sole source agreements (and with respect to the most desirable work, even here as well), firms still have to compete with other preferred providers to gain a larger share of the client's work. Nevertheless, the collaboration, knowledge transfer, and personal connections that these deals are designed to foster has made these relationships a good deal stickier than the still too-often repeated mantra "we hire lawyers, not firms" would lead one to believe. The data from our corporate purchasing survey bears this out. Nearly $80 \%$ of the general counsel in our sample claimed that at most they had terminated an important law firm relationship "once or twice" between 2003 and 2006, with almost a third (31\%) conceding that they had never done so during the period. Only $21 \%$ claimed to have terminated such relationships more than twice, with only $1 \%$ insisting that they had done so frequently. 152

The fact that companies rarely terminate important law firm relationships should not be taken to mean that companies are generally satisfied with the service that they are receiving. To the contrary, there is widespread evidence that general counsel are often quite unhappy about the price, quality, and overall responsiveness of the work of their outside counsel. Rather, as Tyco's Faure discovered, the deeper and more multilayered these relationships become, the harder-and riskier-they are to change. As the former general counsel of a major financial firm once told me, changing these relationships is "like turning the Titanic"-it takes an enormous amount of time and energy, and while you are trying to do it there is always the chance that you'll hit an iceberg.

Whether we call these new arrangements strategic alliances, partnerships, or a legal keiretsu, it is evident that the relationship between large companies and their primary outside law firms is increasingly being defined by the kind of cooperative/competitive relationships that have become ubiquitous in other parts of the new economy. ${ }^{153}$ It is worth asking, therefore, how this new relationship is likely to affect the profession's core values of client service and professional independence.

\section{PARTNERS OR PROFESSIONALS?}

Not surprisingly, the parties responsible for pressing these new arrangements do not see themselves as promoting a new model of the corporate attorney-client relationship-let alone creating a new paradigm

152. See Beardslee et al., supra note 76 , at 29 ; see also Rees W. Morrison, The Truth Behind Those 'Firings,' LeGAL Times (Wash., D.C.), Mar. 19, 2007, at 44.

153. As Charles F. Sabel and Jonathan Zeitlin conclude about the ubiquity of such relationships generally, "Under the name of Japanese production methods (a misnomer, because they have become common knowledge in manufacturing and design), these methods are today a familiar part of the new economy." Charles F. Sabel \& Jonathan Zeitlin, Neither Modularity nor Relational Contracting: Inter-firm Collaboration in the New Economy, 5 ENTERPRISE \& SOC'Y 388, 397 (2004). 
for lawyer professionalism. ${ }^{154}$ Nevertheless, the changes described in Part II are likely to have important consequences for how lawyers understand and carry out their various professional roles. These developments, in turn, may have important implications for clients, lawyers, and for the public.

Before proceeding, however, a word of caution is in order. As should be clear from the discussion above, the new model of the corporate attorneyclient relationship I am describing is still very much in its nascent form. There is very little solid evidence of exactly what is going on, let alone about how these changes are affecting the conduct-and even more the professional self-understanding - of lawyers. Moreover, whether and how the new relationships that have been formed between companies and firms over the last decade will continue to develop is contingent on many factors, not the least of which are developments in the economy and the overall global market for legal services. My observations in this section will therefore be both preliminary and speculative. It is precisely because much remains to be determined, however, that it is so important to begin considering these consequences today while there is still time to shape an appropriate response.

\section{A. Clients}

At first blush, it might seem superfluous to discuss the impact of these new developments on clients. It is clients, after all, who have been pushing for the change. Moreover, as indicated above, the dominant theme over the last thirty years has been corporate clients' ability to reduce dramatically the information asymmetries that used to characterize their relationship with outside counsel. In such an environment, it would seem that there would be little danger that these sophisticated parties will not get what they want. ${ }^{155}$ Indeed, as indicated below, in the minds of most commentators the real concern is whether corporate clients will use these new relationships to coopt law firms in a manner that allows them to further entrench their power and influence. ${ }^{156}$

Nevertheless, there are critics who have raised a cautionary flag about whether, notwithstanding all of the hype, "convergence"-particularly convergence in the kinds of large national or global firms that are

154. Indeed, when I called eLawForum's founder to discuss some of the issues in this paper, he professed great surprise that anyone would think his site had anything to do with professionalism or ethics. In this respect these entrepreneurs are quite different from the leaders of the Inside Counsel Movement, who Rosen describes as quite self-consciously engaged in a project to increase their professional standing by reorienting the normative understanding of the lawyer's role. See generally Rosen, supra note 50.

155. I made this point fifteen years ago with respect to corporate clients' ability to prevent what I then described as "agency delicts." See Wilkins, supra note 22. Given the growth in the number and sophistication of in-house counsel since then, this conclusion should be even more true today.

156. For the classic formulation of this concern, see Marc Galanter, Why the "Haves" Come Out Ahead: Speculations on the Limits of Legal Change, 9 LAW \& SOC'Y REV. 95 (1974). 
increasingly competing for this kind of work-is in the best interest of corporate clients. None other than Ben Heineman has been in the forefront of this skeptical group. In a provocative article in The American Lawyer, Heineman openly questioned whether global law firms promising "one-stop shopping" actually "provide the claimed superior service, quality, or price."157 Heineman raises many trenchant criticisms about both the cost structure and the quality control of today's global law firms. ${ }^{158}$ At the heart of his critique is what he labels as a profound "disconnect" between how companies like GE think about productivity - achieving more for less - and the fact that too many law firms define the term as meaning boosting profits by increasing leverage and raising rates. He suggests that "[u]ntil the big, global firms candidly address the ultimate issue of productivity on a 'total cost' (single price) per-matter basis, they will have a hard time being on the same economic page as many corporate clients." 159

Ironically, it is precisely because many GCs agree with Heineman's assessment that they have moved to institute the kind of partnerships I have been discussing. As indicated in Part II, one of the main reasons why companies are concentrating their work in a smaller number of firms is to force these preferred providers to move toward fixed fees and other similar compensation systems in which both the costs and benefits of the representation are shared by both parties. Similarly, by building closer connections with their primary firms, companies hope to be able to monitor attorney performance more effectively, thereby reducing the danger of padding and waste.

More fundamentally, the way that Heineman frames the issue begs a central question whether GCs who have decided to institute some version of the model I have been discussing see it as being at the core of what they are trying to achieve. For Heineman, each legal matter-" [a]n antitrust issue under China's new competition laws, environmental due diligence when purchasing Russian assets"-is potentially "critical to the cross-border transaction and require[s] separate counsel with special expertise."160 But for many general counsel, such "bespoke solutions," to borrow the quaint British phrase Richard Susskind uses in his equally provocative new book The End of Lawyers?, are no longer what they are seeking. ${ }^{161}$ As a legal consultant who has worked with many companies to consolidate their law

157. Ben W. Heineman, Jr., Bigger Isn't Better, Am. Law., Nov. 2008, at 71.

158. Among Heineman's objections are that global firms have an inflated cost structure that requires them to "bill until September" in order to be profitable and that these firms will inevitably have a large "mediocre middle" and little or no common culture that should make companies skeptical of the firm's quality claims-particularly across specialties and geographies. Id. at 72 .

159. Id.

160. Id.

161. See Richard Susskind, The END of Lawyers? Rethinking the Nature of Legal SERVICES 28-36 (2008). 
firm relationships succinctly put it, "A relatively small part of a business corporation's legal function requires that kind of star lawyer."162

To be sure, some legal work is in fact the equivalent of brain surgery. Not surprisingly, arrangements like the one between Tyco and Eversheds exclude this work from the deal, although as indicated above Eversheds is entitled to compete for this "premium work" along with other firms. ${ }^{163}$ But it is also surely true that lawyers-even many in-house lawyerssystematically overestimate how much work truly qualifies for this designation. Moreover, as Susskind persuasively argues, there is a strong tendency for legal work to drift inexorably from "premium" to "commodity" over time. ${ }^{164}$ As a result, clients adopting a "risk assessment" perspective will often view lawyers as far more fungible than those who still think of legal services as fundamentally bespoke. For these clients, having lawyers who "understand their business"-particularly how the business measures and evaluates risk, including legal risk-may be far more valuable than technical competence or skill. Once again, sophisticated corporate clients would appear to be in a good position to make these kinds of trade-offs. ${ }^{165}$

There is, however, an additional concern that, although still within the company's power to control, may nevertheless be more difficult for clients to address since by definition it will only arise once it is too late to correct. As indicated above, the interlocking connections between companies and firms engendered under the new preferred provider models mean that these relationships are a good deal stickier than the prior spot-contracting arrangements. As a result, a company is vulnerable to being caught in the lurch if one of its primary firms fails. Such failures, although still rare, are nevertheless happening with increasing frequency, particularly in the current economic environment. In the last year alone, three major firmsHeller Ehrman, Thelen Reed \& Priest, and WolfBlock--have all closed their doors, and by almost every estimate others are sure to follow. Although many of the partners from these failed enterprises-and even some whole departments-have moved to other firms, the whole point of the kind of strategic alliance about which I have been speaking is that its value extends beyond any particular lawyer or group. ${ }^{166}$ Companies that

162. See Sander, supra note 75 (quoting Hildebrandt International consultant Joel F. Henning).

163. Although this work is not guaranteed, Faure recently reported to me that Eversheds is now getting a significant percentage of this high-end work.

164. See SUSSKIND, supra note 161.

165. The same analysis applies to the criticism that high turnover rates and poor internal control systems at many large law firms may limit the benefit that companies can expect to reap from convergence. To the extent that companies are worried about these problemswhich, I should make clear, I believe that they should be-they have the resources at their disposal to require firms to take appropriate steps to limit the damage. I return to these controls below.

166. To the extent that firms create dedicated "client service teams" to handle a given company's matters across the entire range of the strategic partnership, the client will be able to minimize the lost value of the arrangement if its "team" moves en masse to another firm 
partner with firms that fail will by definition lose this benefit. As the "junior" partner in the team, however, law firms are even more vulnerable to this kind of dislocation.

\section{B. Firms}

As with clients, it might seem self-evident that the law firms that enter into these preferred provider relationships benefit from the arrangements. Clients are the "mother's milk" of law firm life. Law firms that enter into long-term relationships with clients able to provide them with a steady supply of work would appear to have nothing to complain about.

In addition, firms can gain many other potential benefits that go beyond a steady supply of fees. One of the most important promises that firms make to those whom they recruit is that they will provide these young lawyers with excellent training in the skills and dispositions that they need to become accomplished and skilled practitioners. ${ }^{167}$ In recent years, however, this promise has grown increasingly illusory. The reasons for this trend are undoubtedly multiple and mutually reinforcing. Clients, weary of an ever-changing cast of untrained-and undoubtedly relatively unproductive-junior lawyers shuffling in and out of their projects, are increasingly unwilling to pay for the work of first-year and second-year associates. ${ }^{168}$ At the same time, partners eager to boost their profits per partner are unwilling to absorb this cost either. The result, as Ben Heineman and I have elsewhere argued, is a "lost generation" of associates who are coming of age in law firms without proper supervision or training. ${ }^{169}$ This is a disaster for both firms and clients. Law firms (at least until the current downturn) were shedding associates at prodigious rates-in many cases up to twenty-five percent per year. Although young lawyers change jobs for many reasons, recent research on the attitudes and careers of junior associates suggests that a perceived-and, I would argue reallack of training and mentoring in large law firms is a significant cause. ${ }^{170}$

in the event that the primary firm fails. Indeed, this may be one reason why, as I indicate below, our survey suggests that companies are increasingly looking toward the "team" or "group" as the important focus of their relationship with their primary outside firms. Nevertheless, even if an entire client team moves to a new firm-an occurrence, needless to say, that is surely not a given in the wake of a law firm failure-there are still likely to be costs associated with reestablishing the strategic partnership in the new firm.

167. See Wilkins \& Gulati, supra note 60 , at 1608-11.

168. As one general counsel flatly told us, "We finally told all our firms that we would not pay for first-year associates."

169. See Ben W. Heineman, Jr. \& David B. Wilkins, The Lost Generation?, CoRP. Couns., Mar. 2008, at 104. As I have also argued, this lack of training has a particularly devastating impact on black and other minority lawyers. See David B. Wilkins \& G. Mitu Gulati, Why Are There So Few Black Lawyers in Corporate Law Firms? An Institutional Analysis, 84 CAL. L. REV. 493, 564-84 (1996).

170. See generally Ronit DinOVITZER ET AL., AM. BAR. FOUND. \& NALP FOUND. FOR Law CAREer Research \& EdUC., After the JD: First Results of a National Study OF LeGal CAREers (2004) [hereinafter DinOvitzer ET AL., AfTER THE JD I] (reporting that junior associates in large law firms were dissatisfied with the training and mentoring that they received and that dissatisfaction in these areas is highly correlated with a lawyer's 
For their part, clients are likely to have increasing difficulty finding trained third-year and fourth-year associates-particularly ones with experience in handling (and understanding) their business-if most of the talented firstyear and second-year lawyers have already left. 171

By giving both clients and firms a stake in a long-term relationship in which both sides have an interest in the other's success, the new partnerships offer at least some hope of breaking out of this gloomy state of affairs. Once they are freed from the tyranny of hourly billings, clients not only don't mind a young associate sitting in on a deposition or listening in on a phone call, they applaud the process. ${ }^{172}$ For their part, firms welcome the prospect of having a junior lawyer interact with the client or trained to provide an important service, thereby freeing up the time of more experienced lawyers to seek out other opportunities.

But as was the case with clients, law firms also face risks from these new arrangements. As the smaller and more junior member of the partnership, firms face substantially more risks from the failure of their primary clients than the other way around. To see the magnitude of this danger, one needs only to return to the Chrysler analogy. As the bottom has fallen out of the auto market, the Obama Administration has come to realize that it had to do more than bail out GM and Chrysler. It also had to pump billions of dollars into propping up their major suppliers. ${ }^{173}$ Keiretsus link the fate of those in the strategic alliance in good times and in bad-and the more successful the alliance the more difficult it is for the parties to extract themselves from its grip. This is particularly true for the supplier in an economy in which other clients are already spoken for.

The recent tax-product scandals involving the accounting firm of Ernst \& Young and the Dallas law firm of Jenkens \& Gilchrist provide a cautionary

intention to leave his or her current employer within two years). We are in the process of analyzing the data from the study's second wave (examining respondents' careers after seven or eight years in practice) but preliminary results appear to confirm this finding. See generally RONIT DINOVITZER ET AL., AM. BAR. FOUND. \& NALP FOUND. FOR LAW CAREER RESEARCH \& EDUC., AFTER THE JD II: SECOND/RESUlTS FROM A NATIONAL STUDY OF LEGAL CAREERS (2009) [hereinafter DINOVITZER ET AL., AFTER THE JD II].

171. Firms can try to ameliorate this danger by seeding their most promising associates, but as many partners will now concede-albeit candidly-it is becoming increasingly difficult to deliver on their promise of good training for even their most valued associates. See Wilkins \& Gulati, supra note 60, at 1611-13.

172. Indeed, in a particular irony it is likely that many of the associates who leave firms will wind up working in the law departments of the very kind of companies that refused to train them in the first place. Although general counsel will certainly reply that they will be able to weed out those who have actually been trained at the point where they seek to hire these law firm refugees, the difficulty of gaining access to the private information about a given recruit's quality held by firms-information that neither the recruit nor the firm (or the headhunter) has any incentive to disclose-should make companies less than sanguine about their ability to make accurate judgments ex post.

173. David Kiley, Billions for Auto Suppliers' Bailout, Bus. WK., Mar. 19, 2009, http://www.businessweek.com/lifestyle/content/mar2009/bw20090319_960219.htm

(reporting that " $[t]$ he Obama Administration on Mar. 19 created a $\$ 5$ billion fund that guarantees payments to struggling auto suppliers, especially those tied to providing parts to General Motors (GM) and Chrysler that are facing the possibility of bankruptcy"). 
tale. ${ }^{174}$ By all accounts, the accounting and law firms worked side by side developing and marketing a string of tax products that the IRS subsequently determined to be sham transactions whose sole purpose was to help clients avoid paying taxes. Indeed, if anything Ernst \& Young was arguably more culpable since it designed the schemes and reaped most of the profits from the sale of the products. Jenkens's contribution was mainly to produce prepackaged opinion letters blessing the deals for a fee. Yet when the house of cards came tumbling down and the IRS came calling, Ernst \& Young was allowed to pay a fine--albeit of several million dollars-that many knowledgeable observers considered to be little more than a slap on the wrist. Jenkens, on the other hand, was driven out of business. ${ }^{175}$ Why? After the demise of Arthur Andersen the government deemed Ernst \& Young, like GM and Chrysler, too big to fail. ${ }^{176}$ A 300-lawyer regional law firm, Jenkens had no similar protection.

Even less catastrophic changes in a client's fate can place the law firm supplier in a strategic alliance at risk. The Howrey/Unocal deal is again instructive. Notwithstanding delivering results that thrilled its corporate partner, Howrey ultimately lost its preferred provider deal when Unocal was acquired by Chevron, which already had its own law firm relationships. Indeed, even if ownership remains unchanged, the closer a firm gets to its corporate partner, the more the client is likely to view the firm as an extension of its own legal staff. Although obviously beneficial to a law firm in many respects, such closeness can also exact a price on the firm's other client relationships as "preferred" clients seek to prevent "their" lawyers from serving the preferred clients' business competitors, even in circumstances where no formal conflict exists or is likely to materialize. ${ }^{177}$

174. See Milton C. Regan, Jr., Taxes and Death: The Rise and Demise of Jenkens \& Gilchrist (2008) (unpublished manuscript, on file with author). See generally Tanina Rostain, Sheltering Lawyers: The Organized Tax Bar and the Tax Shelter Industry, 23 YALE J. ON REG. 77 (2006).

175. See Tax Shelter Users Reach $\$ 75$ Million Settlement with Firms That Gave Bad Advice (Jan. 13, 2005), http://www.lawcash.com/attomey/3229/ernst-young-internationallawsuit.asp.

176. KPMG avoided indictment in 2005 for similar reasons for conduct that was even more egregious. See Robert Schmidt \& Otis Bilodeau, KPMG May Avoid Indictment As U.S. Pushes Settlement, BLOOMBERG.COM, Aug. 4, 2005, http://www.bloomberg.com/apps/ news?pid $=10000103 \&$ refer=us\&sid=aAysChTpuW6E (quoting several Justice Department officials as saying that they would not indict the firm for fear of "eliminat[ing] thousands of jobs and reduc[ing] the number of major accounting firms to three").

177. As one general counsel stated in a remark typical of what we heard from many others, "We used [another firm] because [our main firm] had a conflict. We were pissed. We'd expect from our major providers that when taking on a matter if it's crystal clear we're going to need help too that they don't take the matter .... [H]opefully someone from our law firms would call us and tell us and ask us if we want to engage them before they accept with a competition." Confidential Interview with No. 1, General Counsel, Investment Bank (Oct. 5, 2006); see also Heineman, supra note 157, at 73 (noting the importance of firms not being on the other side of the client in sensitive policy-level disputes). For a general discussion of the increasing importance of business or positional conflicts, see Dzienkowski, supra note 128. 
Indeed, law firms that enter into these kinds of relationships should be prepared for their client-partners to begin looking into many of their internal practices and procedures. Traditionally, general counsels have shown remarkably little interest in the internal management or practices of the law firms they employed. In our survey, for example, few general counsels rated such factors as the firm's compliance, compensation, or ownership structures as more than "somewhat important" in awarding legal work. ${ }^{178}$ But there are signs that this complacent attitude may be changing. In 2007, for example, Wal-Mart began asking the firms on its preferred provider list whether the "partners" working on the company's matters actually have an equity stake in the firm. ${ }^{179}$ Similarly, the head of the Association of Corporate Counsel called for firms to push back against the 2007 salary increases for first-year associates and to begin inquiring about hours bonuses and other practices that arguably encourage lawyers to run the meter. ${ }^{180}$

As clients invest more in their relationships with their primary law firms, these questions are bound to increase. One can already see the trend with respect to companies that have recently had to terminate an important law firm relationship. As indicated above, such terminations are relatively rare. When terminations do occur, however, these actions appear to be positively correlated with a company's increased interest in internal law firm quality control systems. Thus, among firms in our survey that had not terminated an important law firm relationship in the past three years, more than fifty percent of GCs said that a firm's "quality control systems" were not very important in determining whether a given firm would be hired. ${ }^{181}$ Among those who had more frequent terminations, however, the opposite was true-almost two-thirds rated a law firm's quality control systems as being an important factor in the company's legal purchasing decisions. Whether experiencing a recent termination causes companies to be more concerned with quality control, or companies that have this orientation are more likely to be disappointed with the level of service they are receiving from their law firms, ${ }^{182}$ this evidence suggests that at least some clients are beginning to draw the link between a firm's internal practices and the quality of its work product.

The fact that clients are beginning to look more carefully at a firm's internal structure and practices may end up being a boon for law firms. As many commentators have observed, law firms are probably the worst

178. See Beardslee et al., supra note 76 , at 25.

179. See Sam Shulz, Wal-Mart Puts Foot Down on Rising Legal Fees, LAw360, Nov. 2, 2007, http://www.law360.com/articles/39210.

180. See Aric Press, A Long Time Coming, AM. Law., Dec. 2008, at 96 (reporting on the Association of Corporate Counsel initiative); see also Michelle Madsen, Wal-Mart Memo Slams Associate Pay-Hikes, LeGAL WK., Nov. 9, 2007, http://www.law.com/jsp/ PubArticle.jsp?id=900005495581 (reporting that Wal-Mart was refusing to pay increased rates based on higher associate salaries).

181. See Beardslee et al., supra note 76.

182. Our survey does not allow us to tell in which direction the causation arrow points. 
managed multibillion-dollar businesses in the world. Providing these organizations with an incentive to invest in internal compliance procedures, therefore, could potentially lead to important benefits that might help firms avoid situations like the one that sank Jenkens. ${ }^{183}$ Indeed, recent empirical work confirms that firms that adopt internal compliance mechanisms are less likely to commit certain kinds of ethical violations. ${ }^{184}$ As I argue below, avoiding such situations benefits the public as well as firms.

It is important to concede, however, that the implications of the kind of increased scrutiny and control by clients that these new strategic partnerships tend to produce may not always be so benign for the broader public purposes that lawyers as officers of the legal system are also supposed to serve.

\section{The Public}

In what has become one of the most iconic moments from the U.S. savings and loan (S\&L) crisis of the late 1980s, Judge Stanley Sporkin famously asked "[w]here were [the attorneys]" and "[w]hy didn't any of them speak up or disassociate themselves from the[se] transactions?"185 These questions highlight the central tension in the traditional conception of the lawyer's role. In addition to being zealous advocates for the interests of their clients, lawyers are also supposed to play a broader gatekeeping role in which they both counsel their clients to conform their conduct to legal standards and refuse to cooperate--and in extreme cases, even blow the whistle-when their clients seek to engage in conduct that undermines these standards. As we find ourselves in the grip of the latest round of corporate scandals that have made the $S \& L$ debacle look like petty larceny, it is fair to ask whether the new partnerships being forged by companies and their outside lawyers are likely to undermine the ability of lawyers to play this crucial gatekeeping role.

There is certainly reason to be concerned that it may. As Reineir Kraakman argued nearly a quarter of a century ago, whether lawyers or other professionals are able to act as gatekeepers depends crucially upon the characteristics of the market in which these intermediaries operate. ${ }^{186}$ As

183. Elizabeth Chambliss and I first articulated this position in 2002. See generally Elizabeth Chambliss \& David B. Wilkins, The Emerging Role of Ethics Advisors, General Counsel, and Other Compliance Specialists in Large Law Firms, 44 ARIz. L. REV. 559 (2002). Chambliss has gone on to become the most articulate defender of this position. See, e.g., Elizabeth Chambliss, The Professionalization of Law Firm In-House Counsel, 84 N.C. L. REV. 1515, 1552-72 (2006); Elizabeth Chambliss, New Sources of Managerial Authority (2009) (unpublished manuscript, on file with author).

184. See Christine Parker \& S. Mark, Regulating Law Firm Ethical Infrastructure: An Empirical Assessment of the Potential for Management Based Regulation of Legal Practice (2009) (unpublished manuscript, on file with author) (testing Chambliss and Wilkins's claims about the value of internal compliance procedures in a sample of Australian law firms and finding a statistically significant correlation between procedures adopted and avoiding certain kinds of misconduct).

185. Lincoln Sav. \& Loan Ass'n v. Wall, 743 F. Supp. 901, 920 (D.D.C. 1989).

186. See Kraakman, supra note 16. 
indicated above, this market has been moving steadily in the direction of transferring power from lawyers to clients. Moreover, to borrow William Simon's evocative phrase, there is now an active "market for bad legal advice" in which clients actively shop for lawyers who are willing to give them legal opinions that can help to insulate them from liability or criticism. ${ }^{187}$ As the market for legal services becomes increasingly competitive, there is a danger that lawyers will find it difficult to refuse such requests.

More to the point of the current discussion, convergence may very well increase this danger. As John Coffee notes, one of the factors that distinguishes external gatekeepers such as law firms from their internal counterparts such as in-house counsel is that the former have numerous clients and, therefore, are less likely to be beholden to anyone. But the more a company concentrates its legal work in a single law firm, the larger the potential loss of this client's business will loom in the law firm's decision making - particularly in a world in which other clients are doing the same thing with their preferred providers. Indeed, it is precisely this hope of becoming a "star" client that has been one of the most important drivers of the current convergence boom. It is certainly plausible to expect that clients who enter into such arrangements will expect those who serve them to treat them with the unquestioning deference that "star" status often affords.

Indeed, more may be at stake than simply an increased danger of client pressure. The switch to a "partnering" ethos among outside counsel may threaten the very professional self-conception that made lawyers want to act as gatekeepers in the first place. As Robert Gordon succinctly notes, no gatekeeping regime can survive unless lawyers have a strong desire to be independent from their clients. ${ }^{188}$ Although one can certainly argue how much lawyers have ever displayed this desire in fact-let alone been willing to act on the basis of their status as independent professionals in circumstances where their clients were pressuring them to do otherwise ${ }^{189}$ - lawyers who have wanted to embrace this mantle have been aided by a professional ethos that sharply differentiates law from business. But as Robert Rosen argues, the more lawyers become enmeshed in the client's business, the more they are likely to take on a view of "independence" that stresses the importance of protecting the client from

187. See William H. Simon, The Market for Bad Legal Advice: Academic Professional Responsibility Consulting as an Example, 60 STAN. L. REV. 1555, 1556-58 (2008). Although there has been heated criticism of Simon's contentions about the conduct of academic ethics advisers, no one has seriously challenged his basic claim that clients often demand that their lawyers bless transactions with little or no legal merit.

188. See generally Gordon, supra note 3.

189. See id. at 34; see also Robert L. Nelson, Ideology, Practice, and Professional Autonomy: Social Values and Client Relationships in the Large Law Firm, 37 STAN. L. REV. 503 (1985) (discussing how corporate lawyers have beliefs similar to their clients). But see Gordon, supra note 17; William H. Simon, Babbit v. Brandeis: The Decline of the Professional Ideal, 37 STAN. L. REV. 565 (1985). 
competition and regulatory oversight, as opposed to encouraging the client to comply with legal and policy norms. ${ }^{190}$ Recent empirical research suggests that this may have already happened to many inside lawyers. ${ }^{191}$ By instructing outside lawyers to become "partners" with their major clients who are encouraged to see their primary value as helping client teams deploy legal knowledge to maximize competitive advantage, the new strategic alliances between companies and firms risk turning "independent" lawyers into just another consultant serving business ends. ${ }^{192}$

There is clearly merit in these concerns. Indeed, as I will argue below, this is precisely why it is unhelpful and unwise for scholars and professionals interested in maintaining the lawyer's gatekeeping role to either ignore these developments or to leave them entirely to the realm of private ordering. Nevertheless, before we bemoan a world in which "we are all consultants now," it is important to see that strategic alliances don't so much eliminate the space for gatekeeping as reorient its dynamics. One can begin to see this point by remembering the prevailing account of why outside lawyers were increasingly unable to play their traditional "wise counselor" role during the heyday of the In-House Counsel Movement. In that not-so-distant past, many commentators laid the blame for the decline of the "lawyer statesman" on the fact that partners in law firms no longer had sustained relationships with their corporate clients but were instead only brought in to handle discrete transactions, often at the last minute. ${ }^{193}$ As a result, these critics asserted, lawyers no longer had the opportunity to get to know their clients' business in a manner that would allow them to function like the trusted advisors of old. ${ }^{194}$ Moreover, by shifting work around among many firms, corporate clients were able to play these competing advisors against each other while ensuring that no single firm knew enough to be able to detect or deter the misconduct. ${ }^{195}$ As John Coffee evocatively puts it, "Monogamy has thus given way to polygamy, as the corporation flirts with many outside counsel" thereby "[providing] less

190. See Rosen, supra note 86 . I discuss the difference between these two meanings of "independence" in Wilkins, supra note 22, at 853-73.

191. See generally Robert L. Nelson \& Laura Beth Nielsen, Cops, Counsel, and Entrepreneurs: Constructing the Role of Inside Counsel in Large Corporations, 34 LAW \& SoC'Y REV. 457 (2000).

192. Rosen, supra note 86, at 671-75.

193. See, e.g., KRONMAN, supra note 25 .

194. See id. at 271-314. Many contemporary commentators continue to echo this sentiment. See, e.g., COFFEE, supra note 16, at 194-95 (noting that the relationship between law firms and their corporate clients is now "less intimate, ongoing or fully informed than is the relationship between the same corporation and its outside auditor").

195. See COFFEE, supra note 16, at 226; see also DENNIS F. THOMPSON, POLITICAL ETHICS AND PUBLIC OfFICE 40-65 (1987) (describing the difficulties created by situations in which there are "many hands"). As I explain below, this is precisely what Charles Keating did in the famous Lincoln Savings \& Loan case that gave rise to Judge Sporkin's lament about "where were the lawyers?" that began this section. See supra note 185 and accompanying text. 
shelter ... within the firm for the independent professional who resists the client." 196

The new partnering models provide a hedge against these dangers. As indicated above, the whole point of these new arrangements is to ensure sustained contact between the company and its primary outside firms. Although rarely monogamous (with the notable exception of Tyco and Eversheds), convergence dictates that these arrangements will not have the characteristics of speed dating inherent in the old spot-contracting model either. Lawyers who work in these new arrangements therefore have the potential to see the big picture in a way that their colleagues in firms with more transactional relationships with their clients will have a harder time doing.

Moreover as the Tyco/Eversheds deal underscores, partnering relationships often provide incentives for firms to assist companies in reducing their overall legal costs by recommending measures that help the company prevent legal problems in the first place. Thus, Tyco has agreed to pay Eversheds a six-figure bonus if it successfully reduces lawsuits against the company below historic levels. ${ }^{197}$ Such a payment is pure-profit for the firm and also a significant benefit to the company, which not only saves the cost of legal fees, potential damage awards, and (frequently overlooked) managerial distraction, but also stands to gain significantly from increased customer satisfaction and overall goodwill. ${ }^{198}$ As the recent multi-million dollar fines paid out by Siemens Corporation for violations of the Foreign Corrupt Practices Act underscore, the cost of failing to prevent, or at a minimum detect, illegal conduct by company employees can have consequences for the bottom line that far exceed the cost of legal fees. ${ }^{199}$ It should go without saying that preventing illegal actions by company employees also benefits the public and the rule of law generally. ${ }^{200}$

Moreover, the long-term nature of these new strategic partnerships gives each side an incentive to invest in the long-term health of the other. As indicated above, clients and firms who enter into these arrangements remain distinct entities - and, more importantly, in significant respects competitors. As the Chrysler example underscores, a cooperative relationship between such quasicompetitors will only succeed if each side can credibly signal that

196. COFFEE, supra note 16, at 230.

197. See Steve Hoare, Comeback Kid, LAWYER, May 26, 2009, http://www.the lawyer.com/comeback-kid/132978.article.

198. Significantly, prevention also benefits the self-interest of general counsels who are constantly trying to get management to see that their value lies primarily in reducing the company's exposure to risk. See COFFEE, supra note 16 (describing GCs as being good at prevention even though they are not really independent).

199. See David Crawford \& Mike Esterl, Siemens Pays Record Fine in Probe: $\$ 800$ Million Settlement Will End U.S. Bribery Case for German Conglomerate, WALL ST. J., Dec. 16,2008 , at B2.

200. It is possible that firms may try to reduce lawsuits by helping employees to hide misconduct rather than by eliminating it. This is, however, a risky strategy for both the firm and the company since if the misconduct is eventually detected, the potential exposure could increase dramatically because of the perceived cover-up. 
it will use the power that it will inevitably gain over the other party during the course of the relationship responsibly. 201 As Benjamin Gomes-Casseres argues, such relationships depend upon partners exercising "mutual forbearance" by which "they forgo short-run opportunistic actions in the interest of maintaining the relationship, which they expect will yield longrun benefits."202

To achieve these long-term benefits, both parties must remain "healthy" in every sense of the word. As indicated above, at a minimum this means that both the client and the firm must remain economically viable. But as leading thinkers in both business and the professions underscore, the longterm health and viability of either a company or a professional service firm depends upon more than dollars. To survive and prosper, both kinds of organizations must also have legitimacy among all of their respective core constituencies both inside and outside the organization.

For companies, this means maintaining a strong culture of integrity that will allow the organization both to attract and retain top talent and to engender trust among consumers and regulators. ${ }^{203}$ Indeed, according to one of the most respected voices in business, the more challenging the times the more important it is for a company to have a strong set of core values that it adheres to even in the face of economic uncertainty. ${ }^{204}$ The same is true for law firms. Although the firms surely need to be profitable to survive in today's competitive culture, they also must credibly signal that they exemplify strong ethical values if they want to attract and retain the best lawyers. This was the central value proposition trumpeted by firms during the Golden Age. ${ }^{205}$ Although much has changed since those times,

201. See Benjamin Gomes-Casseres, The Alliance Revolution: The New Shape of BUSINESS RIVALRY 95 (1996) (arguing that alliance partners must "walk a fine line between rivalry and collaboration").

202. Id. at 35 .

203. Ben Heineman has been one of the most ardent and articulate defenders of this view. See Ben W. HeIneman, JR., High Performance with High INTEgrity 1 (2008) ("[C]ontemporary corporations should strive to fuse high performance with high integritythe twin goals of capitalism.").

204. See Jennifer Reingold, Jim Collins: How Great Companies Turn Crisis into Opportunity, FORTUNE, Feb. 2, 2009, at 48, 50 (quoting Collins as arguing that what distinguishes companies that succeed is that they have core values that explain "why it is important that [the companies continue to] exist[]" and that "[t]he more challenged you are, the more you have to have your values"). Collins goes on to give the example of Proctor \& Gamble during the depression: "One of the things that was very distinctive about $P \& G$... was that they said a customer will always be able to depend on the fact that a product is what we say it is-we will always build our reputation on quality. When they were under pressure to start cutting corners or use cheaper ingredients, they just didn't do that." Id. It is important to note that Collins is, as the article describes, a highly respected "management guru" whose books Built to Last and Good to Great have sold more copies than any others in the genre. Id. at 49. As a result, whether or not his diagnosis of what makes companies succeed in difficult times is in fact true, it is likely to be very influential among business leaders.

205. As a particularly effusive advocate of this view put it,

[Large law firms provide] an exceptional opportunity to acquire a liberal education in modern government and society. Such partnerships are likely in the future, as 
evidence from a study of recent law school graduates suggests that maintaining a core commitment to values such as craft and professionalism are still central to recruiting and retaining top talent. ${ }^{206}$ In the absence of this commitment to some distinctive notion of lawyer-professionalism, it is difficult to see why ambitious young women and men should go to law school, or if they do, pursue a legal career, as opposed to a potentially more lucrative career in fields such as investment banking or private equity. ${ }^{207}$

Lawyers can, and should, play a central role in maintaining a company's core values. ${ }^{208}$ Indeed, many general counsels assert that this is at the core of what they do. ${ }^{209}$ But as many commentators have noted, although their position inside the company gives general counsel unique access to, and understanding of, the company's core values, it also can make it difficult for these captive lawyers to distance themselves from the business imperatives that can lead these values to be corrupted for short-term gain. ${ }^{210}$ Outside counsel, therefore, can and should play a role in helping their internal counterparts to counteract this pressure. By ensuring that a company's primary outside counsel have both access to and a stake in the company's long-term future, the new strategic partnerships described above make it more likely that firms will have both the incentive and ability to play this supportive role.

they have in the past, to prepare and offer for public service men exceptionally qualified to serve. The very nature of such a partnership permits a man to do more, not less civic work, and permits him, as a true officer of the court and responsible citizen, more readily to enter public service for various periods and to serve society to his full professional capacity.

arthur H. Dean, William Nelson Cromwell 1854-1948: AN American Pioneer IN CORPORATION, COMPARATIVE AND INTERNATIONAL LAW 86 (1957).

206. See DinOvitzer et AL., AfTER THE JD I, supra note 170 (reporting that the primary reason reported by respondents for why they went to law school was to have a "satisfying career" as opposed to high salaries or prestige).

207. I have elsewhere called this the paradox of professional distinctiveness. In order to compete both with each other and with other professionals, law firms are under tremendous pressure to become more "business-like." But if they become too much like any other business then those seeking only money will rationally move to alternative careers with shorter qualification standards and potentially much higher returns. See generally David B. Wilkins, Partner, Shmartner! EEOC v. Sidley Austin Brown \& Wood, 120 HARV. L. REv. 1264 (2007). Of course, whether alternative careers such as investment banking will remain more lucrative than practicing law after the current economic collapse remains to be seen. See Nate Raymond, Former UBS Banker, Tired of Bonus Politics, Heading to Linklaters, AMLAW DAILY, Apr. 2009, http://amlawdaily.typepad.com/amlawdaily/2009/04/former-ubsbanker-tired-of-bonus-politics-joins-linklaters.html (describing the decision by a former Cravath partner who left that firm in 2005 to join UBS to leave the investment bank in 2009 and join the U.K. law firm Linklaters).

208. See Painter, supra note 131 , at 520-53 (noting the substantial power that outside firms have in structuring the internal dynamics of their corporate clients).

209. See Heineman, supra note 63.

210. See Rosen, supra note 86 , at 658 (noting that because inside lawyers work on business teams, legal work is done in a "managerial frame" creating a danger that these lawyers will view themselves as just another consultant who "add[s] value" and not as "a carrier of independent professional judgment"). 
The Tyco/Eversheds deal is once again instructive. When Trevor Faure took over the legal department in 2004, Tyco had just emerged from a series of ethics scandals that nearly destroyed the company. Faure therefore viewed restoring the company's core values and instilling a culture of compliance to be among his highest priorities. At the same time, Faure had to ensure that the company was able to return to profitability so that it could survive in an increasingly competitive marketplace in which its reputation had been shattered. To accomplish these twin objectives, Faure and his legal team developed a series of training courses about the difference between "sinning" and "winning"-and the importance of obtaining customized legal advice in differentiating between the two in close cases. To be effective, however, the lessons learned in this training had to be reinforced in the business managers' dealings with both inside and outside lawyers. Faure therefore required Eversheds to engage in a range of activities designed to facilitate the development of a common set of values and approach between the company and the firm. Specifically, Faure wanted to ensure that when business managers were confronted with difficult ethical challenges they had an incentive to seek advice from the outside lawyers, and that the advice they received would be consistent with the company's policies and values. To achieve this objective, Eversheds was required as part of the deal to give managers thirty minutes of free legal advice on any matter when requested; to develop and update a set of policies, templates, and checklists on key legal and ethical issues facing each of the company's businesses; to participate in Tyco's legal department training and to include the company's inside lawyers in its training; and eventually to take over the function of training business clients on matters of law and company policy. Although the firm was not directly paid for any of these services, the fact that it would receive a significant bonus for both improving customer satisfaction and reducing the number of lawsuits against the company gave the firm an incentive to take these responsibilities seriously-and, equally important, to press the legal department to ensure that it was doing the same.

One can see a similar set of incentives with respect to the stake that companies have in the long-term reputational health of their outside firms. Corporations need more from their lawyers than simple economic viability. They also seek to appropriate the legitimacy that lawyers receive by virtue of their status as officers of the legal system. Society has given lawyers broad, and in many instances exclusive, access to one of society's most precious and important resources-the law. In return, lawyers are expected to use their power in ways that benefit, or at a minimum do not subvert, the public interest. Notwithstanding the public's ambivalent attitude toward lawyers, this social bargain gives the profession a privileged status in the eyes of state officials and, in many cases, the public as a whole. This legitimacy is one of the benefits corporations receive when they hire outside 
firms. ${ }^{211}$ In order to maintain this privileged status, however, corporate law firms must not be seen as consistently undermining the public purposes of the law. Corporations, therefore, have a stake in ensuring that law firms do not squander this valuable resource by placing the firm's short-term economic gain above its long-term interest in its own legitimacy.

Return again to the Tyco/Eversheds agreement. In addition to providing Eversheds a bonus for reducing the number of cases against the company, the deal also specifies that the firm will receive a bonus if it achieves certain diversity targets. ${ }^{212}$ The fact that elite firms are almost as racially segregated today as they were at the time of Brown $v$. Board of Education ${ }^{213}$ in 1954 stands as an important critique of the profession's adherence to the core-legitimating norm of "Equal Opportunity Under Law." 214 Even if law firms are willing to forgo this legitimacy for the sake of short-term profits, corporations have a stake in helping firms resist this destructive impulse. For it is only if law firms can continue plausibly to hold themselves out as legitimate protectors of public norms that the longterm cooperative venture between these firms and their corporate clients will succeed. This connection between demography and legitimacy helps to explain why diversity initiatives have managed to obtain so much traction in the organized bar. Indeed, in the decade since I first drew this connection, it is fair to say that companies have been more willing to intervene in the internal practices of law firms in the diversity area than in almost any other aspect of a firm's business with the exception of its billing practices. 215

Experience in the diversity area, however, also underscores the potential danger of relying too heavily on private market incentives to achieve public goals. As I have argued extensively elsewhere, the movement to shift the justification for efforts to diversify the legal profession from the civil rights paradigm of "separate is inherently unequal" to a market-based paradigm based on the claim that "diversity is good for business" is fraught with peril. ${ }^{216}$ By their very definition, market-based diversity arguments tie the

211. Indeed, in the eyes of many, corporate firms have been the principal beneficiaries of this legitimacy. See KRONMAN, supra note 25, at 273 (arguing that "[f]or a hundred years the large corporate firm has been the principal standard-bearer of the lawyer-statesman ideal in the sphere of private practice").

212. Hoare, supra note 197.

213. 347 U.S. 483 (1954).

214. See LUBAN, supra note 3, at 252-56 (arguing that "Equal Justice Under Law" is the legal profession's core legitimating ideal).

215. See, e.g., Kellie Schmitt, Corporate Diversity Demands Put Pressure on Outside Counsel, RECORDER (S.F.), Dec. 28, 2006, http://www.law.com/jsp/PubArticle.jsp? $\mathrm{id}=900005470357$. Needless to say, one can certainly question how effective-or even sincere-many of these efforts have been. I return to the issue of effectiveness below. But as damning as this evidence is, it remains clear that companies-and increasingly firms-believe it is important to be seen as being committed to this issue. Firms that are not seen as committed risk losing legitimacy with core constituencies.

216. David B. Wilkins, From "Separate Is Inherently Unequal" to "Diversity Is Good for Business": The Rise of Market-Based Diversity Arguments and the Fate of the Black 
achievement of diversity goals to the logic of the marketplace. That logic, however, is likely to be a good deal less hospitable to diversity as a profitmaximizing goal-and a good deal more troubling in its normative implications-than those who promote this shift typically acknowledge. Thus, while many companies claim to value diversity, when the chips are really on the table far fewer are prepared to make it an important criterion when selecting outside counsel in important cases. ${ }^{217}$ Moreover, in those cases where companies do see a clear business justification for hiring minority lawyers it is often in situations-for example, when looking for a lawyer to defend the company against an employment discrimination suitthat raise troubling implications for both the lawyers involved and for the overall goal of promoting equality. The bottom line is that too much focus on the bottom line runs the risk of promoting the appearance of a commitment to diversity at the expense of producing real results.

The danger is that the new partnering model between clients and firms will have similar consequences with respect to professional independence generally. As Robert Rosen worries, companies that seek to integrate lawyers into their business functions may only value the "appearance of 'independence" "as opposed to any real commitment to public purposes or detachment from client aims. ${ }^{218}$ Clients, after all, want to minimize risk, not wholly eliminate it. As a result, lawyers who come to identify too closely with business teams may begin to "approach managing legal risks with non-compliance as a viable option." 219 More fundamentally, even if one concedes that both clients and firms have a mutual interest in preventing misconduct and reducing risk, there is a danger that the "risk management" perspective that this shared interest engenders will paradoxically diminish "a lawyer's individual responsibility for making moral choices about his role in law and society," inducing "a kind of moral apathy" that will ultimately "hobble[] professional independence."220

As I indicated at the outset, there is merit to these concerns. Nevertheless, as even the harshest critiques of this approach concede, "[r]isk management forces attention to [the] practical consequences of professional responsibility decisions, at least insofar as consequences are

Corporate Bar, 117 HARV. L. REv. 1548 (2004); see also Beardslee et al., supra note 76, at 29.

217. See Wilkins, supra note 216 , at 1575 . Our research on corporate counsel bears this out. Although many general counsels told us that diversity was important to them in our qualitative interviews, in the survey itself this factor was ranked by most GCs as "unimportant" when making important legal purchasing decisions.

218. Rosen, supra note 86, at 649.

219. Id. at 660 .

220. Anthony V. Alfieri, The Fall of Legal Ethics and the Rise of Risk Management, 94 GEO. L.J. 1909, 1939 (2006); see also Milton C. Regan, Jr., Risky Business, 94 GEO. L.J. 1957, 1966 (2006) (arguing that "conceptualizing ethics as a matter of avoiding liability can influence [personal] dispositions, attitudes, and motives, and, therefore, how someone exercises her discretion"); William H. Simon, The Ethics Teacher's Bittersweet Revenge: Virtue and Risk Management, 94 GEO. L.J. 1985 (2006). 
measured by liability."221 Indeed, as the defenders of this approach emphasize, policies and practices that institutionalize the process of uncovering, evaluating, and minimizing risk are essential to combat the organizational dynamics that both contribute to individual misconduct and restrict the ability of lawyers to act as independent gatekeepers. 222 To understand why, it is necessary to look more closely at the relationship between risk, ethics, and rewards in the kind of strategic partnerships being forged by companies and firms.

\section{THE ETHICS AND ENFORCEMENT OF PROFESSIONAL AllianCES}

Like Tyco and Eversheds, when companies enter into long-term relationships with key suppliers, their respective rights and obligations are typically defined by contract. ${ }^{223}$ Because alliance partners are entering into an ongoing relationship that will inevitably change over time, however, these agreements tend to be open-ended, containing "gaps" that must be filled in at a later date by some form of joint decision making. ${ }^{224}$ Although alliance partners often develop institutional arrangements to resolve these unexpected events or to renegotiate difficulties in performance, ${ }^{225}$ ultimately the success of the collaborative venture depends upon their ability to nurture and maintain an ethical value, namely trust. ${ }^{226}$ Ethics, in addition to economics, is therefore at the core of these arrangements. Defining the ethical norms that should govern these ventures-and the connection between these norms and the standard conception of legal ethics-is therefore critical in evaluating whether the move to this new kind of partnership between companies and firms will promote or undermine professional independence. ${ }^{227}$

221. Simon, supra note 220, at 1987.

222. See Anthony E. Davis, Legal Ethics and Risk Management: Complementary Visions of Lawyer Regulation, 21 Geo. J. Legal ETHICS 95, 96 (2008) (arguing that "far from 'undermin[ing] the aspirational tradition of legal professionalism,' as suggested by Professor Alfieri, risk management is actually about institutionalizing precisely those values, and giving them concrete form" (alteration in original) (quoting Alfieri, supra note 220, at 1939)); see also Chambliss \& Wilkins, supra note 183.

223. For an excellent description of the contractual problems caused by these new forms of alliances and the complex ways that customers and suppliers attempt to work around these problems, see generally Gilson et al., supra note 13.

224. See GOMES-CASSERES, supra note 201, at 34-35; see also Gulati \& Sytch, supra note 14, at 41 (arguing that "relationships characterized by high joint dependence foster a culture of 'mutual reliance' in which exchange partners exhibit a decreased proclivity for opportunistic behavior" (citing OLIVER E. WILLIAMSON, THE ECONOMIC INSTITUTIONS OF CAPITALISM: Firms, MARKETS, Relational CONTRACTING 190 (1985))).

225. The Tyco/Eversheds deal, for example, was scheduled to run for two years, but because significant problems arose in the first year, in part because neither party had fully anticipated the difficulty of shifting all of the company's work in such a short space of time, the parties renegotiated important aspects of the deal after the first year. See Lloyd, supra note 91 , at 31 .

226. See generally Ranjay Gulati, Does Familiarity Breed Trust? The Implications of Repeated Ties for Contractual Choice in Alliances, 38 ACAD. MGMT. J. 85 (1995).

227. As Gilson underscores, to maintain these relationships requires a complex combination of normative and structural elements that are "more formal than 'relationships,' 
Although defining appropriate ethical values is therefore necessary, as we have learned from long experience in the field of legal ethics, it is rarely sufficient to ensure compliance with appropriate ethical norms. Ethical duties must be reinforced through institutional mechanisms that promote and monitor compliance-and include a realistic threat of sanctions if those norms are routinely violated or ignored. Enforcement as well as aspiration, therefore, must be a part of any plausible regime of professional ethics. ${ }^{228}$ Once again, understanding the range of actual-and potential-enforcement mechanisms, both public and private, is critical to reaching an overall judgment about the implications for the ideal of professional independence of the move toward strategic alliances between companies and firms.

Each of these dimensions-ethics and enforcement-are large and complex, and what follows neither catalogs the full range of possibilities nor purports to develop a definitive account on either topic. Instead, I want to suggest why neither ethics nor enforcement concerns provide an a priori reason to oppose strategic alliances between companies and firms and to suggest some avenues for using both of these domains to help ensure that the movement that appears to be taking place in this direction will not unduly undermine the legitimate purposes of professional independence, and may even promote these goals. ${ }^{229}$

\section{A. The Ethics of Alliance}

The idea that companies and firms must learn to trust each other if they are to forge an effective partnership might at first blush seem not to require

but designed to facilitate learning among collaborating peers by means much less formal than hierarchical ordering." Gilson et al., supra note 13 , at 446 .

228. The classic text on the relationship between norms and their enforcement is Duncan Kennedy, Form and Substance in Private Law Adjudication, 89 HARV. L. REV. 1685 (1976). For my application of Kennedy's insight about the relationship between the content of a norm and its enforcement to legal ethics, see Wilkins, supra note 22, at 809-12 (discussing the connection between "content" and "compliance" arguments in legal ethics). See also David B. Wilkins, Legal Realism for Lawyers, 104 HARV. L. REV. 468, 481 (1990).

229. I use the qualifier "legitimate" advisedly. There is a long history of lawyers speaking as if "professional independence" is a good unto itself. See, e.g., KRONMAN, supra note 25, at 109-62 (arguing that the ideal that lawyers should be "statesmen" who are sympathetic but ultimately detached from the aims of their clients is ultimately grounded in the professional moral development of lawyers themselves). But while the legal profession cannot survive unless those who enter into it find their careers satisfying--a nonfrivolous question in today's profession-the content of professional norms cannot rest solely (or even largely) on what is good for lawyers. See Wilkins, supra note 27, at 472 (making this point with respect to Kronman's book). Given that the bar has often used the ideal of professional independence as a sword to defeat the kinds of external regulation that might actually give corporate lawyers the incentive to resist the improper demands of their powerful clients, we should be particularly careful about uncritically accepting arguments of this kind as a reason not to explore the types of ethical and regulatory alternatives described below. On the bar's use of independence arguments to restrict public participation in the development of ethical norms, see Deborah L. Rhode, Why the ABA Bothers: A Functional Perspective on Professional Codes, 59 TEX. L. REV. 689, 690-92 (1981). For a more detailed analysis of how external enforcement can promote independence from clients, see Wilkins, supra note 22 , at $863-73$. 
any adjustment in ethical norms. After all, the traditional model of legal ethics is expressly premised on encouraging a trusting relationship between lawyers and clients. ${ }^{230}$ For anyone who has been paying attention to the actual relationship between clients and law firms of late, however, it is painfully evident that there is a significant gap between the ideal and the actual when it comes to mutual trust. Ironically, this is particularly true in the corporate sector, where theory would suggest that the interests of client and firm would be most aligned. ${ }^{231}$ Although inside and outside lawyers are not quite Hatfields and McCoys, these two parts of what is purportedly a common profession have become increasingly distant and antagonistic, often communicating through dueling pronouncements from their respective bar organizations. ${ }^{232}$ Communication at the micro level is often not much better, with clients accusing their law firms of treating them as if they were a money tree just waiting to be shaken down and firms feeling as though their clients are continually demanding them to give unsecured loans with no intention of ever paying them back. ${ }^{233}$ The result is relationships every bit as mistrustful and adversarial as those that characterized the relationship between Chrysler and its suppliers before it moved to the keiretsu model. ${ }^{234}$

To move beyond this impasse and create effective collaborative relationships, companies and firms will have to develop what GomesCasseres calls "relationship capital" by honoring their stated commitments and adhering to norms of "fairness" and "reciprocity." 235 Although the parties can achieve a good deal of what is required by contractual means,

230. See, e.g., Monroe H. Freedman \& AbBe Smith, Understanding Lawyers' Ethics $\S 5.01$, at 129 (3d ed. 2004) (arguing that legal ethics is premised on the clients' need to be able to trust their fate to their lawyer).

231. See John P. Heinz \& Edward O. Laumann, Chicago lawyers: The Social STRUCTURE OF THE BAR 380 (1982) (characterizing the corporate sector of the bar as a "patronage-type occupation ... where corporate clients to a large degree dictate the nature of the work done").

232. Note, for example, the competing positions taken by the American Bar Association and the American Corporate Counsel Association on the issue of multidisciplinary practice in the late 1990s. See Andrew L. Kaufman \& David B. Wilkins, Problems in Professional Responsibility for a ChANGING PROFESSION 651-66 (4th ed. 2002) (discussing this debate).

233. Compare Smith, supra note 145, at 58-60 (quoting Cisco's general counsel as lamenting that the firms the company used before moving to its current preferred provider relationship "shed crocodile tears when they heard we got sued"), with Nathan Koppel \& Ashby Jones, "Billable Hour" Under Attack: In Recession, Companies Push Law Firms for Flat-Fee Contracts, WaLl ST. J., Aug. 24, 2009, at Al (noting that the shift by some companies to flat fees "could further squeeze earnings at top law firms" and quoting a partner complaining that "'a client can't expect to have the absolute best team of [trial] lawyers from a firm, and have the lawyers give up all the other work they could be doing on a regular-fee basis, to work 18 hours a day for months of time on a flat-fee engagement"').

234. One final anecdote: my colleagues at Harvard Law School and I were considering designing a joint executive education program for lawyers from both law firms and general counsel offices but abandoned the idea when too many general counsels indicated that they would not come to such an event.

235. See GOMES-CASSERES, supra note 201, at 87. 
for example by moving to fixed fees, supporting the broader normative aspects of the relationship discussed in the proceeding section will require ethical as well as contractual support. This, in turn, will require revisiting the standard principal-agent conception of the attorney-client relationship.

As indicated above, in theory the agency model gives clients near plenary control over the terms and conditions of the lawyer-client relationship. Although this helps to ensure loyalty by lawyers, it raises significant problems for developing and preserving a relationship of mutual trustparticularly one that incorporates public-regarding commitments on both sides. ${ }^{236}$

Consider the client's unqualified right to dismiss a lawyer for any reason. ${ }^{237}$ This right is a natural outgrowth of the agency model. ${ }^{238}$ It also hands corporate clients a potent sword to pressure lawyers into engaging in risky or unethical conduct. In the infamous Lincoln Savings and Loan debacle, for example, Charles Keating deftly used this authority to put pressure on lawyers from the law firm of Kaye, Scholer, Fierman, Hayes and Handler not to question his actions regarding the management of the thrift. Thus, when the law firm initially handling the regulatory. audit insisted that Lincoln disclose certain questionable transactions to regulators, Keating fired that firm and brought in Kaye Scholer. ${ }^{239}$ The lesson was not lost on lawyers at the newly hired firm, who vowed to avoid the "situation of mutual distrust and animosity" that was caused by the prior firm's tough stance regarding Keating's questionable practices. ${ }^{240}$ To make matters worse, under the governing ethical rules applicable at the time, the prior firm not only had no power to contest the dismissal on grounds of public policy, but was equally powerless to disclose what it almost certainly

236. Jack Coffee cites exactly this problem as the reason for dismissing legal ethics as a plausible foundation for establishing an effective gatekeeping role for corporate counsel:

Because legal ethics at its core views the attorney as a client-serving professional who is not permitted to dominate the relationship (and because market conditions make it unlikely that lawyers could do so today), legal ethics does not hold out a practical remedy for gatekeeper failure. One must therefore look beyond legal ethics and the moral exhortations it provides to find a realistic means to empower the attomey as gatekeeper.

COFFEE, supra note 16 , at 229 . The fact that the move toward strategic alliances between lawyers and firms alters the market conditions that inhibit gatekeeping implies that a move away from the client-serving agency model might actually produce real results.

237. See Model RUles OF Prof'l Conduct R. $116 \mathrm{cmt}$. (1983) (noting that a client has an unqualified right to fire his or her lawyer "at any time, with or without cause").

238. See Henry, Walden \& Davis v. Goodman, 741 S.W.2d 233, 236 (Ark. 1987) ("The relationship between the attorney and his client must be based upon the utmost trust and confidence .... The exercise of the right to discharge an attorney with or without cause does not constitute a breach of contract because it is a basic term of the contract implied by law into it by reason of the nature of the attorney-client relationship ....").

239. See generally William H. Simon, The Kaye Scholer Affair: The Lawyer's Duty of Candor and the Bar's Temptations of Evasion and Apology, 23 LAW \& SOC. INQUIRY 243 (1998). For my own take on the case, see Wilkins, supra note 4.

240. See Wilkins, supra note 4, at 1208 n.256 (quoting an internal Kaye, Scholer memorandum). 
suspected to be criminal or fraudulent conduct by Lincoln-even to Kaye Scholer. ${ }^{241}$

Nor was this the only way in which Keating sought to exploit his power as principal in Lincoln's relationship with its lawyer-agents. In addition to holding the sword of Damocles over Kaye Scholer's head, Keating also assiduously controlled the information that was given to any of the many firms representing the thrift. As a result, no single law firm working for the thrift-let alone any single lawyer-had a complete understanding of Lincoln's practices, thereby making it easier for Keating to hide his illegal conduct. Reports about the conduct of company officials at Enron and WorldCom suggest that Keating was far from alone in using this power to ensure that legal work is sufficiently fragmented such that no one can take the long view and "the broader interests of the corporation ... go unrepresented."242 Although critics of these practices have urged lawyers to reject this kind of narrow framing, ${ }^{243}$ as John Coffee accurately notes, such calls "exist in considerable tension with traditional legal ethics," which, consistent with the agency model, gives clients sole authority to define "the objectives of representation."244 Consequently, as Coffee concludes, in many recent scandals the problem is not so much that lawyers were at the scene of the crime but chose to look the other way, but rather that "lawyers were nowhere near the scene of the crime, thereby enabling others to orchestrate the fraud." 245

To move beyond this state of affairs, it is necessary to construct an account of legal ethics that helps to place lawyers in a position to detect client misconduct - and to give them the power to try to deter what they see. Structurally, as indicated above, the new strategic alliances between companies and firms are likely to place lawyers in a better position to be at the "scene of the crime"-or better yet, the place where the crime may be

241. See Model Rules of Prof'L Conduct R. 1.6 (1983) (providing that a lawyer may only breach confidentiality to prevent a future crime involving death or serious bodily harm, or in a dispute with the client or in a proceeding involving the lawyer's representation of the client); see also Philip B. Heymann \& Lance Liebman, The Social Responsibilities of LAWYERS: CASE STUDIES 193-95 (1988) (describing the infamous OPM Leasing case in which a lawyer who resigned because he discovered evidence that his client was engaged in a massive fraud felt compelled by the confidentiality rules not to reveal what he knew to successor counsel). Ironically, the successor lawyer involved in OPM was none other than Peter Fishbein, who subsequently was the lead lawyer for Kaye Scholer in the Lincoln Savings \& Loan case. I discuss the changes to Rule 1.6 and other related rules that would have altered what would have been permissible for lawyers in the Lincoln and OPM cases below.

242. See COFFEE, supra note 16 , at 225-26.

243. See, e.g., Robert W. Gordon, A New Role for Lawyers?: The Corporate Counselor After Enron, 35 CONN. L. REv. 1185 (2003).

244. See COFFEe, supra note 16, at 226 (citing MOdEl RULES OF PROF'L CONDUCT R. 1.2 (2003)). As Coffee goes on to say, "If the organization as client wants to use outside counsel in a narrow fashion, asking them only technical questions and structuring the relationship so that outside counsel is neither invited nor equipped to provide 'holistic' advice, the organization would seem entitled to do so." Id.

245. Id. at 231 . 
averted - than the spot-contracting model manipulated by Charles Keating. But if the lawyers are to utilize their newfound knowledge, the ethical restrictions that discourage them from doing so ought to be removed. The logic of embeddedness that characterizes these cooperative relationships suggests that parties should not engage in deception, coercion, or other forms of pressure tactics designed to force the other partner into violating a legal or ethical duty. ${ }^{246}$ To the extent that a company has breached this ethical duty to its outside firm, there would seem to be little reason to reward it for transgressing such a fundamental part of the joint relationship. Although a contrary rule surely raises difficult questions about how such an obviously strained attorney-client relationship will be managed, courts do not hesitate to compel lawyers to continue representing clients in circumstances where the lawyer does not want to continue because of a disagreement with the client. ${ }^{247}$ At a minimum, the logic of these new relationships suggests that clients should pay some penalty for dismissing an attorney for failing to breach one of the lawyer's own ethical duties.

Indeed, one can see the recent changes in the confidentiality rules enacted by the American Bar Association as nodding in the direction of acknowledging the fundamental unfairness of the traditional agency model in a world in which lawyers are almost as vulnerable to client manipulation as the other way around. After steadfastly resisting the imposition of all but the most minimal gatekeeping-let alone whistle-blowing-duties, the ABA amended the Model Rules in 2002 and 2003 to give lawyers significantly greater latitude to disclose client fraud. Thus, Model Rule 1.6 governing confidentiality has been changed to allow lawyers to disclose information when reasonably necessary to prevent a client from "committing a crime or fraud that is reasonably certain to result in substantial injury to the financial interests or property of another" or to "prevent, mitigate or rectify" financial injury "that is reasonably certain to result or has resulted from the client's commission of a crime or fraud."248 In both of these instances, however, the lawyer can only blow the whistle if the client has used the lawyer's services in furtherance of the criminal or fraudulent conduct. 249 In other words, clients like Charles Keating who involve their lawyers unknowingly in their fraudulent schemes, or who

246. See Gulati \& Sytch, supra note 14 , at 61 (emphasizing that the logic of embeddedness is mediated by the amount of "joint action" between the parties and that this factor significantly "contributes to the enhanced performance of the relationship as a whole and its increased value-generating potential").

247. See Bd. of Prof'l Responsibility of the Supreme Court of Tenn., Formal Ethics Op. 96-F-140 (1996) (refusing to allow a lawyer appointed to represent a minor seeking an abortion to resign because the lawyer was morally opposed to the procedure under any circumstances). Given that corporate clients are sophisticated repeat players who must operate every day in relationships that are less than ideal, the argument that the rule allowing clients to fire their lawyers for any reason is necessary to preserve the client's right to effective legal representation rings hollow in the face of cases that require individual lawyers with strong moral objections to do otherwise.

248. See MOdel RULES OF PROF'L CONDUCt R. 1.6(b)(2)-(3) (2007).

249. Id. 
dismiss their lawyers for failing to cooperate in further misconduct, risk empowering their former advisers to disclose the fraud in order to protect themselves from the deleterious consequences of their client's overreaching. ${ }^{250}$

The amendments to Model Rule 1.13, which governs the duties of lawyers who represent "organizational" clients such as corporations, arguably go even further. Beginning in 2003, lawyers who believe that a corporate manager has acted or is about to act-or refuse to act--in a manner that constitutes "a violation of a legal obligation to the organization" or that may result in a "violation of law that reasonably might be imputed to the organization" are given three interlocking protections against being ensnared in the client's wrongdoing. First, the lawyer is required to report what he knows to "higher authority in the organization, including, if warranted ... to the highest authority that can act on behalf of the organization as determined by applicable law."251 Secondly, if that authority "insists upon or fails to address in a timely and appropriate manner" conduct that the lawyer believes is "clearly a violation of law" and is "reasonably certain to result in substantial injury to the organization," the lawyer "may reveal" whatever information the lawyer "reasonably believes necessary to prevent substantial injury" to her organizational client. ${ }^{252}$ Finally, a lawyer who "reasonably believes that he or she has been discharged" or forced to withdraw for reporting conduct under either of the above two provisions, "shall proceed as the lawyer reasonably believes necessary to assure that the organization's highest authority is informed of the lawyer's discharge or withdrawal." ${ }^{253}$ Collectively, these three provisions both require that lawyers ensure that their real client-the "organization" (at least as represented by the board)-is aware of any potential misconduct by corporate managers or employees that might harm the organization's real long-term interests, while giving them at least some leverage against retaliation by those who might be tempted to ignore the lawyer's advice or punish him or her for trying to give it.

To be sure, these reforms continue to leave the heart of the agency model in place. None of these changes, for example, alter a corporate client's fundamental right to exclude lawyers from the venues where important decisions are made or to strategically manipulate the information the lawyer receives. A complete account of the ethics of lawyer-client strategic alliances would have to define client obligations as well as lawyer rights.

250. Of course, if the lawyer did know about the fraud (or turned a blind eye under circumstances in which such knowledge can reasonably be inferred) and continued to actively assist the client, he or she would not only be guilty of violating the ethics rules but (most likely) the substantive law as well. See MODEL RULES OF PROF'L CONDUCT R. 1.2(d) (2007) ("A lawyer shall not counsel a client to engage, or assist a client, in conduct that the lawyer knows is criminal or fraudulent ....."). I return to the question of how the substantive law regulates lawyer conduct below.

251. Id. R. 1.13(b).

252. Id. R. $1.13(\mathrm{c})$.

253. Id. R. 1.13(e). 
To begin to articulate such an account of "client ethics," however, necessarily requires moving beyond the domain of legal ethics. Whatever their other virtues, the Model Rules of Professional Conduct cannot bind nonlawyers. Although one can try to infer client duties from either the general moral commitments that all members of society share, or the special responsibilities that corporations owe to society, any system that purports to bind credibly companies to adhere to norms of trust and reciprocity with law firms that acknowledge that lawyers have public duties to the legal framework as well as private obligations to clients will inevitably require an engagement with substantive law. ${ }^{254}$

\section{B. Regulating Reciprocity}

Even the modest progress that the profession has achieved since 2002 in moving away from a completely client-centric agency model of legal ethics toward one that gives lawyers at least some tools to protect themselves against client opportunism can be traced to the threat of state regulation. The rules permitting lawyers to disclose contemplated or completed financial frauds were proposed as part of the original text for the Model Rules of Professional Conduct in 1981, only to be repeatedly and vociferously voted down for almost twenty years. Only the public outcry over Enron and related scandals and the threat of the imposition of even more fulsome reporting requirements by Congress galvanized the bar to adopt these provisions. Indeed, the ABA's House of Delegates refused to impose mandatory "up-the-ladder" reporting requirements in Model Rule 1.13 until the beating of the wings of the Sarbanes-Oxley Act (SOX) made it painfully clear that in the absence of some amendment, the profession's entirely discretionary version of that rule would soon be rendered entirely superfluous. Even then, the bar adopted a version of Rule 1.13 that is significantly weaker than the statutory duty imposed by SOX. ${ }^{255}$

It is not surprising that Congress passed rules of conduct creating more stringent gatekeeping duties on lawyers than the profession was inclined to

254. See COFFEE, supra note 16 , at 372 (arguing that regulation will be required to allow gatekeepers to function in a world where they can "demand fuller disclosure, to report misconduct up the ladder, and to search for information the corporation wanted not to disclose"). For my prior analysis of the limited ability of "general moral" and "corporate social responsibility" arguments to generate robust ethical duties by clients to promote diversity in law firms, see Wilkins, supra note 11, at 868-75.

255. Although the trigger for up-the-ladder reporting under SOX is notoriously murky, the Act nevertheless sets an objective standard for defining the lawyer's duties in this area. See Sarbanes-Oxley Act of 2002, Pub. L. No. 107-204, \$307, 116 Stat. 745, 784 (codified as amended in scattered sections of 15 U.S.C. (2006)); SEC Rule, 17 C.F.R. $\S 205.2(\mathrm{e})$ (2009) (mandating up-the-ladder reporting if there is "credible evidence, based upon which it would be unreasonable ... for a prudent and competent attorney not to conclude that it is reasonably likely that a material violation has occurred"). Model Rule 1.13, on the other hand, still requires that the lawyer has actual knowledge of a material violation before he or she is required to report conduct to a higher authority in the organization. MODEL RULES OF PROF'L CONDUCT R. 1.13 (2007); see also id. R. 1.0(f) (defining "knows" as "denot[ing] actual knowledge of the fact in question"). 
impose on itself. The bar is well aware that what I have elsewhere called "institutional controls," such as SEC enforcement, are far more likely to detect a lawyer's violation of public gatekeeping duties than the profession's own disciplinary system, and, even more importantly, to impose significant sanctions when violations are brought to the surface. 256 Indeed, this realization helps to explain the curious phenomenon of bar leaders actively lobbying against the SEC's proposed rule requiring a lawyer who discovers that his corporate client has used his work product to engage in criminal or fraudulent conduct to make a "noisy withdrawal" in which the lawyer expressly disavows his prior work product, even though such conduct is arguably already permissible in approximately forty states. ${ }^{257}$ The question remains, however, whether these and other recent statutory attempts to regulate lawyer conduct can play a positive role in encouraging lawyers to take their public gatekeeping roles seriously, notwithstanding the fact that the developments described in this paper are likely to place outside counsel in long-term relationships with clients that blur the traditional boundary between law and business.

Although the evidence is both preliminary and mixed, there is at least some indication that these regulatory changes are having a positive effect on lawyer independence. Tanina Rostain, for example, reports that interviews with ten general counsels from large companies revealed a much higher commitment by respondents to assert "jurisdiction over questions of legal risk" and to embrace broad gatekeeping duties than reported in earlier studies. ${ }^{258}$ Although Rostain is careful not to read too much into these findings given both the small sample size and the many factors that potentially distinguished her respondents from those involved in prior studies, she nevertheless finds support for the view that SOX has empowered general counsel to play a more active role in gatekeeping. As one respondent summarized,

"[Directors and senior managers] are afraid of going to jail. It is very effective in that way, in my view. It is almost to the point where you have to bend over backwards not to be shrill. And when you play the compliance card, make sure you mean it because you are going to stop these guys in their tracks.... Once you say compliance, you are very, very empowered. The thing about Sarbanes-Oxley that I don't like ... I think it is overkill in a variety of areas, but the power ... to mandate a culture of compliance is very strong." 259

256. See Wilkins, supra note 22 , at $835-38$.

257. See COFFEE, supra note 16, at 221-23 (describing the bar's successful efforts to beat back this rule).

258. See Tanina Rostain, General Counsel in the Age of Compliance: Preliminary Findings and New Research Questions, 21 Geo. J. LeGAL ETHICS 465, 473 (2008). Rostain compares her results to the relative unwillingness by general counsels to act as "cops" found in studies conducted by Nelson and Neilsen and Robert Rosen in the 1990s and 1980s respectively. See generally Nelson \& Nielsen, supra note 191; Rosen, supra note 50.

259. Rostain, supra note 258, at 489 (quoting the general counsel of a medical device company). 
Surveys of the attitudes of general counsel after the passage of the Act appear to support this conclusion, as does the fact that many companies increased their spending on outside counsel during this period. ${ }^{260}$

This dynamic highlights a key feature of the current approach to regulating corporate conduct. In addition to setting out mandates and penalties, contemporary regulatory schemes governing corporate conduct employ incentives to encourage companies to create internal compliance regimes that diffuse regulatory norms throughout the organization. As Rostain explains, in these new regulatory schemes "[c]orporations are expected to install controls-including ethics codes, self-audit mechanisms, compliance training, whistleblower protections, and the designation of compliance personnel-at every organizational level to minimize the risk of unlawful and unethical behavior."261

These regulatory regimes make it clear that responsibility for compliance will be jointly shared among lawyers, managers, and other professionals who possess relevant technical competence or expertise. The growth of the kind of strategic alliances between companies and law firms discussed above further highlights that the "lawyers" involved in helping to establish and operate these new compliance mechanisms will come from both inside and outside the company. All of this underscores the need to develop an account of how these diverse professionals can collaborate in ways that further, rather than frustrate, the public goals underlying these new compliance systems.

John Coffee, for example, proposes that companies be required to have their annual and quarterly disclosure documents reviewed by an "independent" attorney from outside the company, who, "after reasonable inquiry," would then be required to certify that the disclosures were not materially misleading. ${ }^{262}$ Lawyers who failed to discharge this new duty competently under Coffee's proposal could be sued under the securities laws for aiding and abetting their client's fraud. ${ }^{263}$

By highlighting how regulation can be used to impose duties on clients that in turn support the public gatekeeping responsibilities of outside counsel, Coffee's proposal is a step in the right direction. But in trying to "restor[e] the principal-agent relationship between lawyers and investors"

260. See Martin C. Daks, Compliance, Not Legal Fees, Named as GCs' Chief Concern, N.J. L.J., Nov. 1, 2006, http://www.law.com/jsp/ihc/PubArticleIHC.jsp?id=1162289115195 (reporting that in a survey of general counsel in 169 companies, eighty-six percent listed "'keeping track of company activities that might have legal implications"” as their number one concern); see also Conley, supra note 68 (reporting that "GCs-buffeted by regulatory changes from the Sarbanes-Oxley Act, an increasingly risk-averse corporate environment and CEOs who want cost containment and more value from in-house law departments-are turning to outside lawyers with greater frequency").

261. Rostain, supra note 258 , at 480 . Examples of this new regulatory approach can be found in fields as diverse as environmental protection policy to antiterrorism and employment discrimination regulation. See id. at 466-67.

262. See CoFFEE, supra note 16, at 231.

263. Id. at 351 . 
by creating a special role for "disclosure counsel," 264 while keeping the traditional "hired gun" model of the lawyer-agent endorsed by Lord Brougham in place for the rest of the company's counsel, Coffee risks minimizing the effectiveness of the former while exacerbating the problems of the latter. Although companies would presumably have to share information with their disclosure counsel, these same clients would have no incentive to do so with all of the other lawyers involved in the company's complex compliance machinery. Nor would the hired-gun agents have any power or incentive to protest this fate. Indeed, it is entirely possible that Coffee's proposal could drive the vast majority of lawyers not acting as disclosure counsel to give up their gatekeeping roles altogether while at the same time encouraging the company to treat their disclosure counsel as little more than an agent of the government who the company should regard in the same way that it views the SEC. ${ }^{265}$

Moreover, as important as the goal of ensuring proper disclosure under the securities laws is to the overall functioning of our market economy, this is hardly the only place where we want lawyers to act as public gatekeepers. As indicated above, the new regulatory focus on compliance has resulted in the creation of numerous gatekeeping regimes. It is difficult to see, however, how Coffee's proposal could be replicated across all of these diverse regulatory domains. Should Congress seek to create a dedicated "compliance counsel" in every instance in which the statutory scheme contemplates public gatekeeping? If so, how would these new compliance specialists interact with each other, and with lawyers not in this role who, according to Coffee, would continue to operate under Brougham's hiredgun agency model? As others have noted, there is already a burgeoning industry of "law consultants" claiming to assist companies in defining and implementing these new compliance mandates. ${ }^{266}$ Although creating a separate "compliance counsel" might prevent the legal profession from losing market share to these new competitors (many of whom, as Rostain notes, are themselves lawyers) it might also entrench the kind of turf wars that will only work to obscure the fundamental purpose underlying these

264. Id. at 347-52.

265. Although any proposal to create a class of specialists with enhanced responsibilities for gatekeeping runs the risk of diminishing the importance that lawyers not in this role place on these public duties, Coffee's proposal seems particularly likely to produce this result. A law firm general counsel, for example, is specifically charged with interacting with the firm's partners and associates in order to remind them of their individual professional obligations. See generally Davis, supra note 222. Coffee's proposal, on the other hand, seems to contemplate that disclosure counsel, who by definition will come from a different law firm than the other lawyers working for the corporation, should perform their role independently without seeking to influence what the company's other lawyers are doing. Indeed, given that disclosure counsel would be assuming all of the risks of nondisclosure, it may even be difficult to get lawyers to assume this new role since malpractice insurance and other related costs would likely be quite high.

266. See generally Christine PARKer, The Open Corporation: EFFective SelfREgUlATION AND DEMOCRACY (2002); Tanina Rostain, The Emergence of "Law Consultants," 75 FORDHAM L. REV. 1397 (2006). 
regulatory schemes - that achieving effective compliance is the joint responsibility of legal and business professionals. To achieve this goal it is necessary to move beyond a regulatory focus that assumes that gatekeeping duties are the sole responsibility of a single actor.

\section{CONCLUSION: WHERE DO WE GO FROM HERE-COMMUNITY OR CHAOS? ${ }^{267}$}

As I write this article, the market for corporate legal services is being radically transformed-or at least so it seems. Law firms have shed associates-and even partners-faster than GM has laid off autoworkers. And perhaps in a harbinger of GM's fate, many brand name law firms have already shuttered their doors and more are almost certain to follow.

If anything, fate (or to be more accurate, greed) has been even less kind to many of the clients who have traditionally supported these legal giants. There are no investment banks anymore (unless you count Raymond James), and there has been a precipitous decline in the deal market that these former trophy clients helped to support.

Needless to say, I do not pretend to know where all of this is heading even in the next six to twelve months, let alone in the next five to ten years. My guess is that nobody does. Specifically, although it appears that we have reached a significant fork in the road that could bring about a fundamental restructuring of the Cravath model of the large law firm, it is wise to remember that reports of the model's demise have been greatly exaggerated in the past. ${ }^{268}$ Nevertheless, it does feel like the ground is shifting in important ways. I close by saying a few words about what these changes might portend for the legal keiretsus discussed here.

First, it seems likely that the contraction in both client and law firm markets will accelerate many of the trends cited above. Even those companies who survive the downturn intact are going to look aggressively for places to cut costs. The legal department, with its high fixed costs and indirect contribution to the bottom line, is likely to be a prime candidate. Although all of the headlines have been about law firm layoffs, many companies have already begun downsizing their general counsel offices as well. ${ }^{269}$ As in-house legal offices shrink, companies are likely to become even more dependent upon their relationships with outside firms.

Consider, for example, the "Value Challenge" initiative recently launched by the American Corporate Counsel Association (ACC). Based on a series of off-the-record discussions between companies and firms, the Value Challenge seeks to "reestablish trust and improve [the attorney-

267. With apologies to the Reverend Dr. Martin Luther King, Jr.

268. The consulting firm McKinsey \& Company famously wrote a report in the late 1990 s predicting that Cravath would no longer exist as an independent firm by the turn of the century. We all know how that one worked out.

269. See Lynne Marek, Layoff Pain Migrates In-House, NaT'L L.J., Mar. 23, 2009, http://www.law.com/jsp/article.jsp?id=1202429290561 (reporting attorney layoffs at Hyatt, Cigna, eLoyalty, Motorola, Yahoo!, and even GE). 
client] relationship, on both sides" by assuring "an adequate flow of work so that outside lawyers understand the client better and can be more efficient in what they do," while at the same time "get[ting] junior lawyers better trained" and creating incentives to "better budget and manage costs and staffing." 270 To further these goals, clients and lawyers are asked to sign a "Covenant" under which both sides agree to undertake affirmative duties to create a new mutually productive partnership between companies and firms. Companies are asked to take a number of measures, including "[d]efin[ing] our objectives in the engagement" and "[p]rovid[ing] training opportunities for your associates," designed to signal the corporation's "[u]nderstand[ing] our relationship is built on mutual trust" and to "[h]elp nurture an enduring relationship with the firm, not just individual lawyers."271 Outside counsel, in turn, is asked to promise that it will "[l]earn your business and strategic objectives," "[u]se the most appropriate staffing" to "[s]eek to reduce our costs creatively and constantly," and to "[w]ork hard to retain and reward personnel that embrace these concepts, and ensure every member working on your project walks this talk." 272 As the blog entry from Sun Microsystems general counsel Mike Dillon, featured prominently on the ACC's home page for the Value Challenge, makes clear, the fact that "we are in the early stages of a seismic shift in the traditional cost and delivery model for legal services" will only accelerate the need for the kind of commitments by both clients and firms set out in the "Covenant." 273

Secondly although many law firms will undoubtedly try to resist the move to flat fees and other similar initiatives proposed by client initiatives like the "Value Challenge," in the end many will come to realize that they have little choice but to do whatever it takes to solidify and deepen their relationships with their primary clients. As the number of such "trophy" representations shrink-along with the legal budgets of those clients who remain-a spot on a company's preferred provider list will become as precious as it is rare. Law firms are likely to compete aggressively for the honor.

Tyco and Eversheds are a case in point. In the fall of 2009, the two parties agreed to renew their exclusive deal for another two years. Although the deal omits many of the performance bonuses and incentives contained in the original deal, instead relying on a mix of fixed and discounted fees, both sides have made clear that this transition is a sign of the strength, rather than the weakness, of their joint relationship. As Eversheds's managing partner stated when announcing the new deal, "II is

270. See Ass'N Of Corporate Counsel, ACC Value Challenge: Briefing PaCKage 3 (2009), available at http://www.acc.com/valuechallenge/resources/upload/ACC-ValueChallenge-Briefing-Package.pdf.

271. Id. at 4 .

272. Id.

273. The Legal Thing: Notes from a General Counsel, http://blogs.sun.com/dillon/ (June $18,2009,15: 53$ EST). 
a reflection of the maturity of the relationship between Eversheds and Tyco and a benefit of information that we now have that the bonus-related elements have been taken out. Both sides are happy about delivery and have been able to structure the contract accordingly."'274 For its part, Tyco underscored the company's commitment to the relationship by expanding significantly the number of "major projects" that Eversheds will undertake for the company and giving the firm the exclusive right to handle all of Tyco's intellectual property work. ${ }^{275}$ Faure's departure undoubtedly had something to do with the fact that some of the contract's more innovative incentive mechanisms have been dropped. ${ }^{276}$ It is also clear, however, that these provisions had already accomplished a good deal of their intended effect. In the previous two years, Eversheds met the contract's goal for improving customer satisfaction and exceeded the target for reducing litigation filed against Tyco. ${ }^{277}$ Although one can debate whether this success obviated the need for the kind of win-win incentives built into the original deal, 278 the fact that both parties were willing not only to extend their keiretsu-like relationship, but expand it, is yet another indication of how the tightening of the legal market is likely to encourage both companies and firms to build and retain similar kinds of partnering relationships.

Although such intense competition could easily further suppress the willingness of firms to carry out their public gatekeeping responsibilities, the increased regulatory scrutiny that is certain to follow on the heels of the current crisis will push against this natural tendency. Companies in the

274. Claire Ruckin, Tyco and Eversheds Overhaul Relationship and End Bonuses, LEGAL WK., Nov. 5, 2009, http://www.legalweek.com/legal-week/news/1561035/tyco-evershedsoverhaul-relationship-bonuses (quoting Bryan Hughes, Chief Executive, Eversheds).

275. Id. (reporting that "major projects" will constitute $60 \%$ of the work Eversheds handles for Tyco under the new agreement - up from $20 \%$ under the initial deal in 2007and that Eversheds will now handle all of the company's intellectual property work).

276. See id. (noting that the bonuses were introduced in 2008 , "with former general counsel Trevor Faure then describing them as 'pure added value for pure profit"').

277. Id. (noting that Eversheds had hit the client satisfaction and exceeded the litigation reduction target); see also Eversheds, The Groundbreaking Tyco/Eversheds Relationship Continues, http://www.eversheds.com/uk/Home/about_us/how_we_work_with_you/casestudies.page (last visited Mar. 28, 2010) (reporting that "Tyco has been pleased with a 27 per cent reduction in legal spend and an astonishing 60 per cent drop in the number of disputes it has had to endure in its litigation portfolio").

278. In a conversation with the author about why the incentives he had negotiated had been dropped in the new deal, Trevor Faure indicated that Evershed's success in meeting these initial targets indicated that there may no longer have been a need for further incentives of this kind. Although this may be a plausible explanation, the fact that the diversity targets were also omitted even though Eversheds failed to meet this goal suggest that it may not be a complete explanation. See Ruckin, supra note 274 (reporting that Eversheds failed to meet the diversity target); see also Eversheds, supra note 277 (quoting David Symonds from Tyco's legal department as stating, "I thought the previous contract was complicated" and that "'bonus' is a dirty word at the moment," particularly to business people). Even those who ultimately decided to modify the agreement, however, conceded that the original incentive scheme "served a purpose in that it has driven the right behaviours." Id. (quoting Symonds). 
financial services industry are about to face the kind of regulatory onslaught not seen since the New Deal. And just like that historic period, this new environment will ultimately be a boon for lawyers-particularly lawyers who can help companies credibly signal to regulators and the public that they are operating in a manner that will not threaten to drive the proverbial bus, as President Obama likes to refer to the economy, into a ditch again anytime soon. ${ }^{279}$ In such an environment, it is at least plausible that independence could become the new cool. Indeed, since some of the new regulatory attention is bound to be directed toward sharpening the bar's gatekeeping duties, lawyers are likely to have a personal stake in insuring their-and their client's-rectitude.

Needless to say, there are likely to be other less happy consequences as well. Law firms that are squeezed for cash are less likely to devote some of these scarce resources to causes that they still think of as charity, such as pro bono and diversity - particularly if shell-shocked law students and associates stop inquiring about these issues. Given that the attention devoted to these issues even in good times is relatively low, this could be a substantial blow.

Even here, however, there is the potential for a silver lining. In a tacit recognition of the important role that pro bono and diversity have come to play in defining the legitimacy of the attorney-client relationship, the ACC's "Value Challenge Covenant" specifically calls on clients and firms to both maintain and support their own, and each other's, pro bono and diversity efforts. ${ }^{280}$ Moreover, to ease the pain of deferred start dates and mandatory furloughs, many firms are giving their erstwhile associates stipends to work in public interest or government jobs while partners wait to see if the Obama stimulus package can jump-start the corporate legal market. ${ }^{281}$ Some of those who take advantage of this option will undoubtedly like their public jobs and stay. Most, however, will probably decide to return to the firms that have furloughed them-but hopefully with a renewed commitment to public ideals to go along with their new understanding of the reality that even the safest choices may be less safe than one has been led to believe.

This movement between public and private is, of course, simply the latest (if unexpected) manifestation of the increasing volatility of legal careers. In the After the $J D$ study, we found that even after two to three years, many young lawyers had not only changed jobs but also moved across sectors. 282

279. See Peter Sher, Lessons for U.S. Corporate Law Firms from the Great Depression (2009) (unpublished manuscript, on file with author) (documenting how many of today's leading law firms rose to prominence during the Great Depression by displaying a flexibility to changed circumstances that allowed them to take advantage of the regulatory and market reforms of the New Deal and speculating that there will be similar winners emerging out of the current crisis).

280. ASS'N OF CORPORATE COUNSEL, supra note 270 , at 4.

281. Stephanie Chen, For Jobless Lawyers, Plan B Includes Good Works, CNN.COM, Apr. 13, 2009, http://www.cnn.com/2009/CRIME/03/16/lawyer.layoff.public/index.html.

282. DINOVITZER ET AL., AFTER THE JD I, supra note 170, at 53-54. 
Our preliminary analysis of Wave II suggests that this trend has only accelerated as the class of 2000 moves toward early middle age. ${ }^{283}$

The fact that lawyers are likely to move across sectors with greater frequency in the coming years, however, raises an important challenge for the kind of analysis I have presented here. The model of the attorney-client relationship I have been exploring is based on the particular dynamics of the relationship between large companies and equally large law firms. In the prevailing sociological account, these actors constitute a distinct "hemisphere" of legal practice that is separate from what these theorists charmingly called the "personal plight" sector of the bar. ${ }^{284}$ But as lawyers increasingly move across this divide-often repeatedly-we will have to rethink whether the jurisdictional boundaries between different areas of practice, and different kinds of client relationships, will continue to holdand if not, what to make of it.

The same point can be made about law firm boundaries. In our study of how corporations purchase legal services, we found a surprising willingness for companies to treat the "team" or "work group" as being even more important than either the firm or the individual in deciding how to administer punishment when it is disappointed in the services it receives on a particular matter. ${ }^{285}$ If this trend continues, the important unit of analysis might shift significantly-undermining the ability of "companies" and "firms" to forge the kind of cooperative relationships examined here.

As I indicated at the outset, developing a model of the attorney-client relationship that adequately accounts for these rapidly moving changes is a large and difficult task, and I certainly make no claim to have delivered the last word here. ${ }^{286}$ Instead, I will simply plead that no plausible account of legal ethics can avoid these vexing questions. The nature of the lawyer's role inevitably places those who occupy this position at the intersection of competing normative and institutional worlds-law, business, policy, family, and nation. It is up to those of us who have the luxury to think about these issues at some remove from the front lines to help those in the trenches - and those who depend on lawyers to carry out both their public and their private duties-to navigate among these competing domains without either being crushed, or, to return for one final time to Brougham, "involv[ing] [the] country in [too much] confusion." 287

283. Dinovitzer ET AL., AFTER THE JD II, supra note 170.

284. See HEinz \& LaUMANN, supra note 231 , at 72 n.11.

285. See Beardslee et al., supra note 76.

286. For my prior punting of this issue, see Wilkins, supra note 228

287. 2 TRIAL OF QUEEN CAROLINE 3 (New York, James Cockcroft \& Co. 1874). 